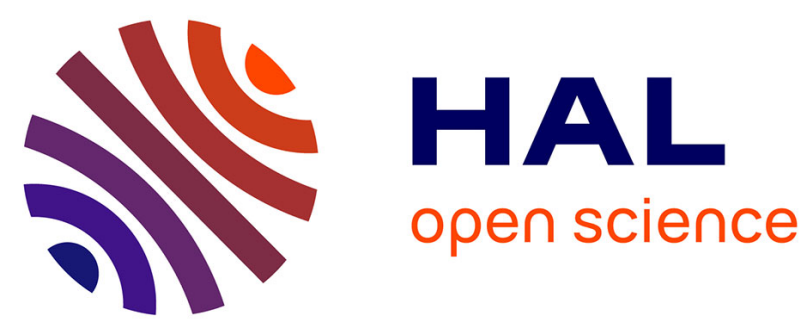

\title{
Geochemical modeling of Fe(II) binding to humic and fulvic acids
}

\author{
Charlotte Catrouillet, Mélanie Davranche, Aline Dia, Martine Bouhnik-Le \\ Coz, Remi Marsac, Olivier Pourret, Gérard Gruau
}

\section{To cite this version:}

Charlotte Catrouillet, Mélanie Davranche, Aline Dia, Martine Bouhnik-Le Coz, Remi Marsac, et al.. Geochemical modeling of $\mathrm{Fe}(\mathrm{II})$ binding to humic and fulvic acids. Chemical Geology, 2014, 372, pp.109-118. 10.1016/j.chemgeo.2014.02.019 . insu-00965127

\section{HAL Id: insu-00965127 https://hal-insu.archives-ouvertes.fr/insu-00965127}

Submitted on 24 Mar 2014

HAL is a multi-disciplinary open access archive for the deposit and dissemination of scientific research documents, whether they are published or not. The documents may come from teaching and research institutions in France or abroad, or from public or private research centers.
L'archive ouverte pluridisciplinaire HAL, est destinée au dépôt et à la diffusion de documents scientifiques de niveau recherche, publiés ou non, émanant des établissements d'enseignement et de recherche français ou étrangers, des laboratoires publics ou privés. 


\section{Geochemical modeling of Fe(II) binding to humic and fulvic acids}

Charlotte Catrouillet ${ }^{\mathrm{a} *}$, Mélanie Davranche ${ }^{\mathrm{a}}$, Aline Dia ${ }^{\mathrm{a}}$, Martine Bouhnik-Le Coz ${ }^{\mathrm{a}}$, Rémi Marsac ${ }^{\mathrm{b}}$, Olivier Pourret ${ }^{\mathrm{c}}$, Gérard Gruau ${ }^{\mathrm{a}}$

\footnotetext{
a Géosciences Rennes UMR 6118, Université Rennes 1, CNRS, 35042 Rennes cedex, France

${ }^{\mathrm{b}}$ Institute for Technology, Institute for Nuclear Waste Disposal, D-76021 Karlsruhe, Germany

${ }^{c}$ HydrISE, Institut Polytechnique LaSalle Beauvais, 60026 Beauvais cedex, France

* Corresponding author: charlotte.catrouillet@univ-rennes1.fr, +33 (0)2 23235458
}

Keywords : Iron(II), humic substances, complexation, sorption, PHREEQC-Model VI, PHREEPLOT

\section{ABSTRACT}

The complexation of $\mathrm{Fe}(\mathrm{II})$ with organic matter (OM) and especially with humic acids (HA) remains poorly characterized in the literature. In this study, batch experiments were conducted on a pH range varying from 1.95 to 9.90 to study HA-mediated Fe(II) binding. The results showed that high amounts of $\mathrm{Fe}(\mathrm{II})$ are complexed with $\mathrm{HA}$ depending on the $\mathrm{pH}$. Experimental data were used to determine a new set of binding parameters by coupling PHREEPLOT and PHREEQC-Model VI. The new binding parameters (log $\mathrm{K}_{\mathrm{MA}}=2.19 \pm 0.16$, $\log \mathrm{K}_{\mathrm{MB}}=4.46 \pm 0.47$ and $\Delta \mathrm{LK}_{2}=3.90 \pm 1.30$ ) were validated using the LFER (linear free energy relationship) method and published adsorption data between Fe(II) and Suwannee River fulvic acid (SRFA) (Rose and Waite, 2003). They were then put in PHREEQC-Model VI to determine the distribution of $\mathrm{Fe}(\mathrm{II})$ onto $\mathrm{HA}$ functional groups. It was shown that $\mathrm{Fe}(\mathrm{II})$ forms mainly bidentate complexes, some tridentate complexes and only a few monodentate complexes with $\mathrm{HA}$. Moreover, $\mathrm{Fe}(\mathrm{II})$ is mainly adsorbed onto carboxylic groups at acidic and neutral $\mathrm{pH}$, whereas carboxy-phenolic and phenolic groups play a major role at basic $\mathrm{pH}$. The major species adsorbed onto $\mathrm{HA}$ functional groups is $\mathrm{Fe}^{2+} ; \mathrm{Fe}(\mathrm{OH})^{+}$appears at basic $\mathrm{pH}$ (from $\mathrm{pH} 8.13$ to 9.9). The occurrence of $\mathrm{OM}$ and the resulting HA-mediated binding of $\mathrm{Fe}(\mathrm{II})$ can therefore influence $\mathrm{Fe}(\mathrm{II})$ speciation and bioavailability in peatlands and wetlands, where 
seasonal anaerobic conditions prevail. Furthermore, the formation of a cationic bridge and/or the dissolution of $\mathrm{Fe}(\mathrm{III})$-(oxy)hydroxides by the formation of $\mathrm{Fe}(\mathrm{II})-\mathrm{OM}$ complexes can influence the speciation of other trace metals and contaminants such as As.

\section{Introduction}

Natural organic matter (NOM) derives from the biological and chemical degradation/transformation of plant and animal residues (Piccolo, 1996). The most refractory and reactive fraction with regards to metal binding is composed of humic substances (HS). Humic substances can be divided into three operational fractions: humic acids (HA) soluble under alkaline conditions, fulvic acids (FA) soluble over the entire $\mathrm{pH}$ range and humins, the insoluble fraction. Humic substances, and especially HA and FA, are considered to exert a major control on metal mobility and bioavailability in the environment (Sposito, 1986; Buffle et al., 1998; Tipping, 2002). They are renowned for their ability to bind a large range of metals and metalloids including possibly toxic elements such as REE, $\mathrm{Al}(\mathrm{III}), \mathrm{Pb}(\mathrm{II}), \mathrm{Ca}(\mathrm{II}), \mathrm{Mn}(\mathrm{II})$, $\mathrm{Mg}(\mathrm{II}), \mathrm{Fe}(\mathrm{III})$ and smaller amounts of $\mathrm{As}(\mathrm{V})$ (Thanabalasingam et al., 1986; Redman et al., 2002; Lin et al., 2004; Buschmann et al., 2004; Bauer et al., 2006; Ritter et al., 2006; Kar et al., 2011), As(III) (Thanabalasingam et al., 1986; Warwick et al., 2005; Buschmann et al., 2006; Liu et al., 2010), Sb(V) (Pilarski et al., 1995; Tighe et al., 2005; Filella et al., 2012) and Sb(III) (Pilarski et al., 1995; Buschmann et al., 2004; Tella et al., 2009; Filella et al., 2012). The high binding capacity of HS is usually attributed to the large surface density of oxygencontaining functional groups (carboxylic, phenolic, carbonyl) and, to a lesser extent, nitrogenor sulfur-containing functional groups (Evangelou et al., 2001). The binding ability of metals to HS has been intensively studied, notably through experimental and modeling studies (Fukushima et al., 1992; 1996; Town et al., 1993; Mota et al., 1994; Pinheiro et al., 1994; Tipping, 1998; Christl et al., 2000; Milne et al., 2003; Nuzzo et al., 2013). However, whereas HS binding with $\mathrm{Fe}(\mathrm{III})$ and $\mathrm{Fe}(\mathrm{III})$-oxyhydroxides has been intensively studied (Weber et al., 2006; Van Schaik et al., 2008; Morris et al., 2012) only very few works have been dedicated 
to the understanding of $\mathrm{Fe}(\mathrm{II})$-HS complexation mechanisms (Schnitzer et al., 1966; Van Dijk, 1971; Rose and Waite, 2003; Yamamoto et al., 2010).

A better understanding and the quantification of $\mathrm{Fe}(\mathrm{II})-\mathrm{HS}$ binding is crucial in the case of reduced waters, such as those occurring in peatlands, wetlands or anoxic sediments. As iron(II), the reduced species of $\mathrm{Fe}$ is much more soluble than $\mathrm{Fe}(\mathrm{III}), \mathrm{Fe}$ (II) concentrations are generally high (i.e. several $\mathrm{mg} \mathrm{L}^{-1}$ ) in these waters (Ponnamperuma, 1972; Buffle et al., 1989; Davison, 1993; Dia et al., 2000; Olivié-Lauquet et al., 2001). In such environments, where soils or sediments are periodically flooded and water-saturated, the organic matter $(\mathrm{OM})$ is slightly degraded. High content of soluble, colloidal or particulate OM, and notably HS, are therefore encountered in these soils and soil solutions. The combination of these two features along with the high metal binding capacity of HS suggests that HS could be an important parameter in these waters, controlling not only the solubility, mobility and bioavailabity of $\mathrm{Fe}(\mathrm{II})$, but also the kinetics of $\mathrm{Fe}(\mathrm{II})$ oxidation and the type of $\mathrm{Fe}(\mathrm{III})$ oxides formed during reoxidation (Pédrot et al., 2011).

Another more indirect reason to study the binding of $\mathrm{Fe}(\mathrm{II})$ by $\mathrm{HS}$ is that this binding could have major implications regarding groundwater contamination by As. Recent studies have shown that reduced, organic-rich sediments from flood plains could be an important source of As for underlying aquifers (Harvey et al., 2006; Kocar et al., 2008; Polizzotto et al., 2008; Fendorf et al., 2010). It has been shown in an oxic environment that $\mathrm{Fe}(\mathrm{III})$, through the formation of ternary complexes with $\mathrm{HS}$, allows the binding of $\mathrm{As}(\mathrm{V})$ as an oxyanion to OM (Sharma et al., 2010; Mikutta et al., 2011). In this type of organic-rich environment, As(V) sorption onto $\mathrm{OM}$ seems to be a controlling factor for As speciation in contrast with previous studies which suggested that Fe-oxyhydroxides control the fate of As. Is it possible that similar complexes are formed between dissolved organic matter (DOM) and As(III) and As(V) in reduced, organic-rich waters, using $\mathrm{Fe}(\mathrm{II})$ as a cationic bridge between DOM and As species? Do these complexes enhance the mobility of As in flood plain sediments and to what extent are they involved in the contamination of underlying aquifers by As? 
To better understand the potential role of HS with regards to $\mathrm{Fe}(\mathrm{II})$ and As mobility in reduced waters, a first step consists of describing and quantifying $\mathrm{Fe}(\mathrm{II})-\mathrm{HS}$ binding. However, very few studies have been conducted to date with this purpose. It is necessary to identify which binding mechanisms are the prevailing ones and to estimate the stability constants of $\mathrm{Fe}(\mathrm{II})$ with $\mathrm{HA}$ and/or FA. Several attempts have been made to do this, but their results are contradictory. Schnitzer and Skinner (1966) established that Fe(II)-FA binding increases with increasing FA concentrations (from 0 to $1 \mathrm{~g} \mathrm{~L}^{-1}$ ) and $\mathrm{pH}$ (from 3.5 to 5 ) with a maximum complexation at $57 \%$ of $\mathrm{Fe}(\mathrm{II})$ for $\mathrm{pH}=3.5$, $[\mathrm{Fe}(\mathrm{II})]_{\mathrm{tot}}=100 \mathrm{mg} \mathrm{L}^{-1}$ and $\mathrm{DOC}=553$ $\mathrm{mg} \mathrm{L}^{-1}$. Van Dijk (1971) proposed from titration experiments that HA complexes $\mathrm{Fe}(\mathrm{II})$ through the formation of bidentate complexes. More recently, Rose and Waite (2003), who studied the kinetics of $\mathrm{Fe}(\mathrm{II})$ binding with 12 different NOMs in coastal waters, showed that Fe(II) binding with soil OM differs from one OM to another. Jackson et al. (2012) and Miller et al. (2009; 2012) studied the ability of OM to delay Fe(II) oxidation in an aerobic environment. Miller et al. (2012) proposed two mechanisms for $\mathrm{Fe}(\mathrm{II})$ oxidation in the presence of OM: first, a one-ligand model with two different oxidation mechanisms; second, they proposed a twoligand model, where $\mathrm{Fe}(\mathrm{II})$ is first complexed with an OM strong binding site, and then with an OM weak binding site. Few datasets are therefore available concerning Fe(II)-HS binding.

These limited datasets could not be used to perform extensive modeling studies on Fe(II)-HS binding. Based on only one dataset (Van Dijk, 1971), Tipping (1998) reported the following $\mathrm{Fe}(\mathrm{II})-\mathrm{HA}$ binding parameters: $\log \mathrm{K}_{\mathrm{MA}}=1.28$ and $\Delta \mathrm{LK}_{2}=0.81$ using Model VI. For the NICA-Donnan model, Milne et al. (2003) did not use Van Dijk's (1971) dataset because this dataset corresponds to $\mathrm{pH}$ data. They simply estimated the $\mathrm{Fe}(\mathrm{II})-\mathrm{HA}$ binding parameters using the LFERs (linear free energy relationship) between their binding parameters and log $\mathrm{K}_{\mathrm{OH}}$, the first hydrolysis constant. Concerning Fe(II)-FA complexation, they used Schnitzer and Skinner's (1966) experimental datasets to determine their values for the binding parameters.

The aims of this study were to describe and quantify $\mathrm{Fe}(\mathrm{II})-\mathrm{HA}$ complexation. Batch experiments involving complexation between $\mathrm{Fe}(\mathrm{II})$ and Leonardite $\mathrm{HA}$ were performed. This 
new experimental dataset was obtained through the coupling of an experimental approach combining ultrafiltration and Inductively Coupled Plasma Mass Spectrometry (ICP-MS) measurements. PHREEPLOT-PHREEQC-Model VI was then used to model the binding of $\mathrm{Fe}(\mathrm{II})$ to $\mathrm{HS}$ using our new dataset and to determine the binding parameters of $\mathrm{Fe}(\mathrm{II}) . \mathrm{A}$ validation of these values for the binding parameters was then performed using the LFER method and by reproducing published data using PHREEQC-Model VI. Speciation on the different sites was then determined, providing complexation mechanisms of $\mathrm{Fe}$ (II) to $\mathrm{HA}$.

\section{Experimental, analytical and modeling methods}

\subsection{Reagents and materials}

All aqueous solutions were prepared with analytical grade Milli-Q water (Millipore). The $\mathrm{Fe}(\mathrm{II})$ stock solutions were prepared with iron chloride tetrahydrate $\left(\mathrm{FeCl}_{2} .4 \mathrm{H}_{2} \mathrm{O}\right)$ from Acros Organics. $\mathrm{NaOH}, \mathrm{HCl}$ and $\mathrm{HNO}_{3}$, all sub-boiling ultrapure grade, came from Fisher Chemical, Merck and VWR, respectively. Ammonium acetate, hydroxyammonium chloride and dimethyl-2,9 phenanthroline-1,10 chlorhydrate were obtained from Fisher Scientific, Merck and VWR Prolabo, respectively.

The HA used was the standard HA Leonardite from the International Humic Substance Society (IHSS). Prior to the experiments, HA molecules $<10 \mathrm{kDa}$ were removed using a Labscale TFF system equipped with a Pellicon XL membrane (PGCGC10, Millipore $^{\mathrm{TM}}$ ). After acidic digestion, blank Fe, Mn and Mg concentrations occurring in HA were determined by ICP-MS. The average concentrations were $206.6 \mu \mathrm{g} \mathrm{L}^{-1}, 1 \mu \mathrm{g} \mathrm{L}^{-1}$ and $13.4 \mu \mathrm{g}$ $\mathrm{L}^{-1}$ for $\mathrm{Fe}, \mathrm{Mn}$ and $\mathrm{Mg}$, respectively.

All materials were soaked in $10 \% \mathrm{HNO}_{3}$ and then rinsed with deionized water twice overnight. All experiments were conducted in a Jacomex isolator glove box $\left(<10 \mathrm{ppm}\right.$ of $\left.\mathrm{O}_{2}\right)$ to prevent the oxidation of $\mathrm{Fe}(\mathrm{II})$ to $\mathrm{Fe}(\mathrm{III})$. 


\subsection{Setup of the binding experiments}

A standard batch equilibrium technique was used. Three series of $\mathrm{Fe}(\mathrm{II})-\mathrm{HA}$ complexation experiments were conducted in triplicate. Firstly, the $\mathrm{pH}$ was monitored and kept constant during $24 \mathrm{~h}$ with a multi-parameter Consort C830 analyzer combined with an electrode from Bioblock Scientific (combined Mettler InLab electrode). Calibrations were performed with WTW standard solutions $\left(\mathrm{pH}=4.01\right.$ and 7.00 at $\left.25^{\circ} \mathrm{C}\right)$. The accuracy of the $\mathrm{pH}$ measurements is $\pm 0.05 \mathrm{pH}$ units. An isotherm adsorption experiment was carried out relative to the increasing $\mathrm{Fe}(\mathrm{II})$ concentration $\left(0.61\right.$ to $\left.8.55 \mathrm{mg} \mathrm{L}^{-1}\right)$. The average concentration of dissolved organic carbon (DOC) was $48.9 \mathrm{mg} \mathrm{L}^{-1}$. The $\mathrm{pH}$ was fixed at 5.9 with ultrapure $\mathrm{HCl}$ and $\mathrm{NaOH}$. Secondly, a pH sorption edge experiment was performed over a pH range from 1.95 to 9.90 with $\mathrm{DOC}$ and $\mathrm{Fe}(\mathrm{II})$ concentrations of 48.8 and $3.03 \mathrm{mg} \mathrm{L}^{-1}$, respectively. Finally, a pH sorption-edge experiment was carried out over a $\mathrm{pH}$ range from 2.95 to 8.89 with $\mathrm{DOC}$ and $\mathrm{Fe}(\mathrm{II})$ concentrations of $76.5 \mathrm{mg} \mathrm{L}^{-1}$ and $3.15 \mathrm{mg} \mathrm{L}^{-1}$, respectively. The $[\mathrm{Fe}(\mathrm{II})]_{\mathrm{tot}}, \mathrm{pH}$ and $\mathrm{DOC}$ concentrations used in these experiments are representative of the concentrations that can be found in wetland waters (Ponnamperuma, 1972; Reddy and Patrick, 1977; Dia et al., 2000; Olivié-Lauquet et al., 2001). The ionic strength of all experiments was fixed at $0.05 \mathrm{M}$ with $\mathrm{NaCl}$ electrolyte solution. Experimental solutions were stirred for $24 \mathrm{~h}$ to reach equilibrium. At equilibrium, $15 \mathrm{~mL}$ of solution was sampled and ultrafiltrated at $5 \mathrm{kDa}$ (Vivaspin VS15RH12, Sartorius) by centrifugation at $2970 \mathrm{~g}$ for $30 \mathrm{~min}$. under $\mathrm{N}_{2}$ atmosphere. Ultracentrifugation cells were previously washed with $0.15 \mathrm{~N} \mathrm{HCl}$ and Milli-Q water to obtain a DOC concentration below $1 \mathrm{mg} \mathrm{L}^{-1}$ in the ulltrafiltrate.

\subsection{Chemical analyses}

Dissolved organic carbon (DOC) concentrations were determined using an organic carbon analyzer (Shimadzu TOC-V CSH). The accuracy of the DOC measurements was estimated at $\pm 5 \%$ for all samples using a standard solution of potassium hydrogen phtalate. Iron concentrations were determined by ICP-MS using an Agilent Technologies 7700x at 
Rennes 1 University. The samples were previously digested twice with $14.6 \mathrm{~N} \mathrm{HNO}_{3}$ at $90^{\circ} \mathrm{C}$, evaporated to complete dryness and then resolubilized with $\mathrm{HNO}_{3}$ at $0.37 \mathrm{~mol} \mathrm{~L}^{-1}$ to avoid any interferences with DOC during the analysis. ICP-MS analyses were carried out introducing $\mathrm{He}$ gas into collision cell to suppress any interference from Ar. The iron interference $\left({ }^{40} \mathrm{Ar}^{16} \mathrm{O} /{ }^{56} \mathrm{Fe}\right)$ was properly reduced by using $\mathrm{He}$ gas into collision cell to reach a low detection limit for Fe analysis (LD Fe: $0.07 \mu \mathrm{g} \mathrm{L}^{-1}$ ) (Instrumental and data acquisition parameters can be found in the supplementary information). Quantitative analyses were performed using a conventional external calibration procedure ( 7 external standard multielement solutions - Inorganic Venture, USA). A mixed solution of rhodium-rhenium at a concentration level of $300 \mathrm{ppb}$ was injected on-line with the sample in the nebulizer. This solution was used as an internal standard for all measured samples to correct instrumental drift and matrix effects. Calibration curves were calculated from the intensity ratios between the internal standard and the analyzed elements. A SLRS-5 water standard was used to check the accuracy of the measurement procedure, and the instrumental error on the $\mathrm{Fe}$ analysis is $<5 \%$. Chemical blanks of Fe were below the detection limit $\left(0.07 \mu \mathrm{g} \mathrm{L}^{-1}\right)$, and were thus negligible.

Concentrations of $\mathrm{Fe}(\mathrm{II})$ in the ultrafiltrate $\left([\mathrm{Fe}(\mathrm{II})]_{\mathrm{UF}}\right.$ ) were determined with the 1.10phenantroline colorimetric method (AFNOR, 1982) at $510 \mathrm{~nm}$ using a UV-visible spectrophotometer (UV/VIS Spectrometer "Lambda 25" from Perkin Elmer). Total Fe concentrations in the mixed HA-Fe(II) solutions were only measured by ICP-MS using the procedure described above. Indeed, the absorbance of Leonardite HA measured at $50 \mathrm{mg} \mathrm{L}^{-}$ ${ }^{1}$ of $\mathrm{DOC}$ is high (more than twice the absorbance of $\left.\mathrm{Fe}(\mathrm{II})\right)$. The error of the $[\mathrm{Fe}(\mathrm{II})]_{\mathrm{UF}}$ and $[\mathrm{Fe}(\mathrm{II})]_{\text {tot }}$ measurements was estimated at less than $5 \%$ above a concentration of $\mathrm{Fe}(\mathrm{II})$ of $0.85 \mathrm{mg} \mathrm{L}^{-1}$ (7\% for a concentration of $\mathrm{Fe}(\mathrm{II})$ of $\left.0.6 \mathrm{mg} \mathrm{L}^{-1}\right)$. Iron (II) concentrations in the ultrafiltrates were assumed to be inorganic $\mathrm{Fe}(\mathrm{II})$, whereas $\mathrm{Fe}(\mathrm{II})$ bound to $\mathrm{HA}$ (Fe(II)-HA) was considered to be the retentate fraction $>5 \mathrm{kDa}$. The fraction of $\mathrm{Fe}(\mathrm{II})$ bound to HA was calculated as $[\mathrm{Fe}(\mathrm{II})-\mathrm{AH}]=[\mathrm{Fe}(\mathrm{II})]_{\text {tot }}-[\mathrm{Fe}(\mathrm{II})]_{\mathrm{UF}}$, with $[\mathrm{Fe}(\mathrm{II})]_{\text {tot }}$ representing the Fe content of 
the mixed $\mathrm{HA}-\mathrm{Fe}(\mathrm{II})$ solutions prior to ultrafiltration and $[\mathrm{Fe}(\mathrm{II})]_{\mathrm{uF}}$ the $\mathrm{Fe}$ concentration determined in the ultrafiltrate by ICP-MS.

\subsection{Determination of the PHREEQC-Model VI binding parameters}

\subsubsection{PHREEQC-Model VI}

In this study, Model VI was coupled with PHREEQC as has been previously done (Marsac et al., 2012). It was used to calculate the partitioning of ions between the various complexing sites available on HS. PHREEQC-Model VI assumes that the complexation of ions by HS occurs through eight discrete sites: four weak sites, named A sites (usually assumed to be carboxylic groups), and four strong sites, named B sites (usually assumed to be phenolic groups). The abundance of type $A$ and $B$ sites are respectively named $n_{A}(\mathrm{~mol} \mathrm{~g}$ $\left.{ }^{1}\right)$ and $n_{B}=0.5 * n_{A}\left(m o l ~ g^{-1}\right)$. The intrinsic proton dissociation constants for type A and B sites and their distribution term are $\mathrm{pK}_{\mathrm{A}}, \mathrm{pK}_{\mathrm{B}}, \Delta \mathrm{pK}_{\mathrm{A}}$ and $\Delta \mathrm{pK}_{\mathrm{B}}$, respectively. The fractions of proton sites that can make bidentate sites and tridentate sites are named $f_{B}$ and $f_{T}$, respectively. Ion adsorption by humic and fulvic substances is described by a specific complexation parameter $\log K_{M A}$ and log $K_{M B}$ for carboxylic and phenolic sites, respectively. The abundance of type $A$ and $\mathrm{B}$ sites, their distribution term and the fraction of sites that can form bidentates and tridentates sites differ from HA to FA. The values of these constants are presented in Table 1 (from Tipping, 2002).

Tipping (1998) established a linear relationship between $\log K_{M A}$ and $\log K_{M B}: \log K_{M B}$ $=3.39{ }^{*} \log \mathrm{K}_{\mathrm{MA}}-1.15\left(\mathrm{R}^{2}=0.80\right)$ to constrain the number of parameters set. This was deleted in PHREEQC-Model VI by Marsac et al. (2011), who determined the binding parameters of the rare earth elements (REE) with HA. The interaction between one site and one ion is characterized by the complexation constant log $\mathrm{K}$. These eight sites can therefore form monodentate, bidentate or tridentate complexes with a given ion. The log $\mathrm{K}$ values are

calculated from (1) $\log \mathrm{K}_{\mathrm{MA}}$ and $\Delta \mathrm{LK}_{1 \mathrm{a}}$ for a monodentate carboxylic site, (2) $\log \mathrm{K}_{\mathrm{MB}}$ and $\Delta \mathrm{LK}_{1 \mathrm{~b}}$ for a monodentate phenolic site, (3) log $\mathrm{K}$ of the two monodentate sites for a weak 
bidentate site, (4) $\log K$ of the two monodentate sites and $1^{*} \Delta \mathrm{LK}_{2}$ ( $9 \%$ of the sites) and $2^{*} \Delta \mathrm{LK}_{2}(0.9 \%$ of the sites) for a strong bidentate site, (5) log $\mathrm{K}$ of the three monodentate sites for a weak tridentate site and (6) $\log \mathrm{K}$ of the three monodentate sites and $1.5^{\star} \Delta \mathrm{LK}_{2}(9 \%$ of the sites) and $3^{*} \Delta \mathrm{LK}_{2}(0.9 \%$ of the sites) for a strong tridentate site. Eighty binding equations are then defined. An electrical double layer is involved in the electrostatic interaction. The thickness of the electrical double layer corresponds to $1 / K$, where $k$ is the Debye-Hückel parameter. The ion distribution between the diffuse layer and the solution volume is calculated by a simple Donnan model.

\subsubsection{PHREEPLOT}

PHREEPLOT is a software used to create graphical output and to fit data using PHREEQC. The 80 complexation equilibria defined in PHREEQC-Model VI for HA and FA were added in the "minteq.v4" database. The humic and fulvic acids were defined as SOLUTION_MASTER_SPECIES, SOLUTION_SPECIES and PHASES. The $160(80 * 2)$ types of sites defined in PHREEQC-Model VI were added as SURFACE_MASTER_SPECIES in the "minteq.v4" database. The aim of the modeling process was to determine the value of $\log K_{M A}$ and $\log K_{M B}$ for $\mathrm{Fe}$ (II) by fitting the concentration of $\mathrm{Fe}(\mathrm{II})$ bound to $\mathrm{HA}$ from experimental data with those calculated by PHREEPLOT. A nonlinear relationship between log $\mathrm{K}_{\mathrm{MA}}$ and $\log \mathrm{K}_{\mathrm{MB}}$ was used as previously performed by Marsac et al. (2011). The specific PHREEQC-Model VI binding parameters, namely $\log \mathrm{K}_{\mathrm{MA}}$, log $\mathrm{K}_{\mathrm{MB}}, \Delta \mathrm{LK}_{2 \mathrm{C}}$ and $\Delta \mathrm{LK}_{2 \mathrm{P}}$, were defined in PHREEPLOT as fitting parameters. Their values were determined by extrapolation of the present experimental $\mathrm{Fe}(\mathrm{II})-\mathrm{HA}$ dataset. Binding parameters were optimized using the weighted sum of squares of the residuals. The stability constants of all sites defined in PHREEQC-Model VI were calculated from log $\mathrm{K}_{\mathrm{MA}}$ and $\log \mathrm{K}_{\mathrm{MB}}$. The reactions necessary for PHREEPLOT calculation were added in the SURFACE_SPECIES section of PHREEPLOT using a different name for 
each constant. The 80 equations defined in PHREEQC-Model VI were added using their SURFACE_SPECIES nomenclature in the PHREEPLOT input as "numericTags".

\subsection{LFER linear free energy relationship}

The PHREEQC-Model VI type A sites represent carboxylic groups of HA or FA. Acetic acid $\left(\mathrm{CH}_{3} \mathrm{COOH}\right)$ can be used as a molecular model of $\mathrm{HA}$ carboxylic groups. Pourret et al. (2007) determined a linear relationship (LFER) between $\log K_{M A}$ and $\log K(M-A A)$, the stability constant of a metal $\mathrm{M}$ with acetic acid:

$$
\log K_{M A}=1.03 * \log K(M-A A)-0.43 ; \quad R^{2}=0.80
$$

Another LFER between log $\mathrm{K}_{\mathrm{MA}}$ and the first hydrolysis constant of a metal $\mathrm{M} \log \mathrm{K}(\mathrm{M}-\mathrm{OH})$ has been suggested by the same authors (Pourret et al., 2007):

$$
\log \mathrm{K}_{\mathrm{MA}}=0.24{ }^{*} \log \mathrm{K}(\mathrm{M}-\mathrm{OH})+0.32 ; \quad \mathrm{R}^{2}=0.78
$$

Marsac et al. (2011) showed that the linear relationship between $\log K_{M A}$ and $\log K_{M B}$ established by Tipping (1998) could not account for the binding of REE with HA. These authors estimated $\log \mathrm{K}_{\mathrm{MB}}$ using the LFER method based on log $\mathrm{K}_{\mathrm{MB}}$ and the metal catechol stability constant (log K(M-catechol)):

$$
\log \mathrm{K}_{\mathrm{MB}}=0,37{ }^{*} \log \mathrm{K}(\mathrm{M}-\text { catechol })+0,86 ;\left(\mathrm{R}^{2}=0.95\right)
$$

\section{Results}

\subsection{Experimental results}

$\mathrm{Fe}(\mathrm{II})_{\mathrm{UF}}$ and $\mathrm{Fe}(\mathrm{II})_{\text {tot }}$ concentrations (data presented in the supplementary information) determined using the phenanthroline method showed that no oxidation of $\mathrm{Fe}(\mathrm{II})$ occurred during any of the experiments. The quantification limit (QL) of the phenanthroline method is $0.5 \mathrm{mg} \mathrm{L}^{-1}$ of $\mathrm{Fe}(\mathrm{II})_{\mathrm{UF}}$ which is $\mathrm{x} 5000$ the $\mathrm{QL}$ of the ICP-MS method $\left(0.12 \mu \mathrm{g} \mathrm{L}^{-1}\right)$. The iron(II) concentrations used in this work were therefore those determined by ICP-MS. 


\subsubsection{Adsorption isotherm}

Fig. 1a presents log $[\mathrm{Fe}(\mathrm{II})-\mathrm{HA}]$ according to log $[\mathrm{Fe}(\mathrm{II})]_{\mathrm{uF}}$. At low $[\mathrm{Fe}(\mathrm{II})]_{\mathrm{uF}}$ concentrations $\left(\log [\mathrm{Fe}(\mathrm{II})]_{\mathrm{UF}}=-6.2\right)$, $\log [\mathrm{Fe}(\mathrm{II})-\mathrm{HA}]$ was approximately -5.0 and increased progressively to reach -4.28 for the maximum $\log [\mathrm{Fe}(\mathrm{II})]_{\mathrm{UF}}$ value used $\left(\log [\mathrm{Fe}(\mathrm{II})]_{\mathrm{UF}}=-4.00\right)$. The lack of any plateau suggests that the saturation of HA complexation sites was not reached.

\subsection{2. $\mathrm{pH}$ sorption edge}

$\mathrm{pH}$ sorption edge experiments are very useful to better constrain the values of the binding parameters. Indeed, at acidic $\mathrm{pH}$, the HA sites are protonated and only strong sites are able to bind cations. At basic $\mathrm{pH}$, all sites are deprotonated and able to bind cations. Fig. 1b displays the proportion of $\mathrm{Fe}(\mathrm{II})$ bound to $\mathrm{HA}$ in the $\mathrm{pH}$ range 1.95 to 9.90 (DOC $=48.5$ $\mathrm{mg} \mathrm{L}^{-1}$ ). At $\mathrm{pH}=1.95$, only $4.1 \%$ of the total $\mathrm{Fe}(\mathrm{II})$ was complexed with $\mathrm{HA}$. The adsorbed $\mathrm{Fe}$ (II) percentage then increased progressively with increasing $\mathrm{pH}$ to reach $51.3 \%$ at $\mathrm{pH}=$ 4.99 and $>99 \%$ at $\mathrm{pH}>8.13$. Fig. $1 \mathrm{c}$ displays the adsorbed $\mathrm{Fe}(\mathrm{II})$ percentage at $\mathrm{DOC}=76.5$ $\mathrm{mg} \mathrm{L}^{-1}$ in the $\mathrm{pH}$ range 2.95 to $8.89 .17 .6 \%$ of the total $\mathrm{Fe}(\mathrm{II})$ was bound to $\mathrm{HA}$ at $\mathrm{pH}=2.95$, with this amount reaching $62.9 \%$ and $>99 \%$ for $\mathrm{pH}$ values $=4$ and 8.89 , respectively. Both $\mathrm{pH}$ sorption edge experiments exhibited the same trend, but the percentages increased with the increasing DOC concentration.

\subsection{Model results}

As explained in section 2.4, we used the coupling PHREEPLOT-PHREEQC-Model VI to simultaneously fit all our datasets. We determined the following values for the $\mathrm{Fe}(\mathrm{II})$ binding parameters (without the linear relationship between $\log K_{M A}$ and $\log K_{M B}$ ): $\log K_{M A}=$ $2.19 \pm 0.16, \log \mathrm{K}_{\mathrm{MB}}=4.46 \pm 0.47$ and $\Delta \mathrm{LK}_{2}=3.90 \pm 1.31$ with $\mathrm{R}^{2}=0.97$.

\subsubsection{Adsorption isotherm}

The root-mean-square error (RMSE) was calculated as RMSE $=\sqrt{\text { mean }\left(\log v_{\text {exp }}-\log v_{\text {calc }}\right)^{2}}$ where $v_{\text {exp }}$ and $v_{\text {calc }}$ are the amounts of Fe bound to $H A$ per gram of DOC for the experimental and modeled data, respectively. The modeled data 
were plotted as a solid line in Fig. 1a. The fit goodness of the adsorption isotherm was validated by the RMSE value of 0.09 . $\log [\mathrm{Fe}(\mathrm{II})-\mathrm{AH}]$ and $\log [\mathrm{Fe}(\mathrm{II})]_{\mathrm{uF}}$ increased as the $[\mathrm{Fe}(\mathrm{II})]$ total concentration increased (Fig. 1a). The modeled data were close to the experimental data as shown by the RMSE equal to 0.08 for this dataset. In Fig. 1 a, the first points, $\log [\mathrm{Fe}(\mathrm{II})-\mathrm{HA}]=-4.95$ and -5 , were both far from the modeled data compared to the other points. Despite the fact that the fit appears to be visually poor at low concentrations, the RMSE is good. This can be explained by the scale used here $(\log [\mathrm{Fe}(\mathrm{II})])$, which reinforces the differences. We tried to improve the fit for the points at low concentrations using the new parameters, but the fits for the global $\mathrm{pH}$ adsorption edge were worse. Furthermore, these parameters did not involve any modifications of the Fe(II) speciation on the HA sites. Therefore, we chose the set of binding parameters that provided the best RMSE.

\subsection{2. $\mathrm{pH}$ adsorption edge}

The percentage of adsorbed $\mathrm{Fe}(\mathrm{II})$ increased with increasing $\mathrm{pH}$ in both experiments (DOC concentration $=48.8 \mathrm{mg} \mathrm{L}^{-1}$, Fig. $1 \mathrm{~b}$ and $76.5 \mathrm{mg} \mathrm{L}^{-1}$, Fig. 1c). The RMSE for the first dataset $\left(\mathrm{DOC}=48.8 \mathrm{mg} \mathrm{L}^{-1}\right.$, Fig. $\left.1 \mathrm{~b}\right)$ is equal to 0.11 . The experimental percentage of adsorbed $\mathrm{Fe}(\mathrm{II})$ was higher than in the simulation at $\mathrm{pH}=6.94$ and 8.13 , but lower than in the simulation at $\mathrm{pH}=5.90$ and 2.99, explaining this high $\mathrm{RMSE}$. For the second dataset $(\mathrm{DOC}=$ $76.5 \mathrm{mg} \mathrm{L}^{-1}$, Fig. 1c) the RMSE is much lower (0.06) indicating a better fit between the modeled and experimental data. In both cases, the $\mathrm{pH}$ adsorption edge showed low $\mathrm{Fe}(\mathrm{II})$ complexation by $\mathrm{HA}(<20 \%)$ at acidic conditions $(\mathrm{pH} \leq 3)$, the complexation becoming instead nearly quantitative $(>90 \%)$ at $\mathrm{pH}>7$.

\subsection{Fe(II) speciation onto HA binding sites}

Speciation was calculated from the fit of the experimental data using PHREEQCModel VI. PHREEQC-Model VI is able to calculate the proportions of $\mathrm{Fe}$ (II) bound to each site defined in the model: phenolic (sum of $\mathrm{Fe}(\mathrm{II})$ bound to phenolic monodentate, pheno- 
phenolic bidentate and pheno-pheno-phenolic tridentate groups), carboxylic (sum of $\mathrm{Fe}(\mathrm{II})$ bound to carboxylic monodentate, carboxy-carboxylic bidentate and carboxy-carboxycarboxylic tridentate groups), carboxy-phenolic (sum of $\mathrm{Fe}(\mathrm{II})$ bound to carboxy-phenolic bidentate, carboxy-carboxy-phenolic and carboxy-pheno-phenolic tridentate groups), etc. The complex denticity was also determined: monodentates correspond to the sum of $\mathrm{Fe}(\mathrm{II})$ bound to carboxylic and phenolic groups, bidentates to the sum of Fe(II) bound to carboxyphenolic, pheno-phenolic and carboxy-carboxylic groups and tridentates to the sum of $\mathrm{Fe}(\mathrm{II})$ bound to carboxy-carboxy-carboxylic, carboxy-pheno-phenolic and pheno-pheno-phenolic groups.

\subsubsection{Adsorption isotherm}

The majority of $\mathrm{Fe}(\mathrm{II})$ (between 73.1 and $83.9 \%$ of $\mathrm{Fe}(\mathrm{II})$ ) was bound to $\mathrm{HA}$ by bidentates. The remaining Fe(II) was mainly bound through tridendate sites (20\%), as the amount of $\mathrm{Fe}(\mathrm{II})$ bound through tridentate sites is insignificant $(<1 \%$, Fig. 2a). Moreover, the proportions of $\mathrm{Fe}(\mathrm{II})$ bound to carboxylic, carboxy-phenolic and phenolic functional groups were $50 \%, 40 \%$ and $10 \%$, respectively (Fig. $2 \mathrm{~b}$ ). All Fe(II) bound to $\mathrm{HA}$ was in the form of $\mathrm{Fe}^{2+}$ (Fig. 2c).

\subsection{2. $\mathrm{pH}$ adsorption edge}

In the experiment conducted with a DOC concentration of $48.8 \mathrm{mg} \mathrm{L}^{-1}$, more than $80 \%$ of $\mathrm{Fe}(\mathrm{II})$ bound to $\mathrm{HA}$ formed bidentates and approximately $15 \%$ formed tridentates. The number of monodentate sites was insignificant in this experiment $(<1 \%$, Fig. 3a). The $\mathrm{pH}$ did not influence their distribution, but strongly controlled the nature of the functional groups involved. Thus, the proportion of carboxylic groups decreased from $>80 \%$ at $\mathrm{pH}=$ 1.95 to $<10 \%$ at $\mathrm{pH}=9.90$ (Fig. $3 \mathrm{~b}$ ), which was compensated by an increased role of carboxy-phenolic sites, which accounted for between 20 and $60 \%$ of the $\mathrm{Fe}(\mathrm{II})$ binding with increasing $\mathrm{pH}$. Some phenolic sites were also involved (up to $20 \%$ at $\mathrm{pH}=9.90$ ), but only at high $\mathrm{pH}$. From acidic to neutral $\mathrm{pH}$ conditions, all $\mathrm{Fe}(\mathrm{II})$ bound to $\mathrm{HA}$ occurred as $\mathrm{Fe}^{2+}$ (Fig. 3c). The Fe-OH ${ }^{+}$species appeared only from $\mathrm{pH}=8.13$ (1.35\% of $\mathrm{Fe}(\mathrm{II})$ bound to $\left.\mathrm{HA}\right)$, with 
the proportions of this species then increasing with increasing $\mathrm{pH}$ to reach $38.5 \%$ at $\mathrm{pH}=$ 9.90 .

In the experiment conducted with a DOC concentration of $76.5 \mathrm{mg} \mathrm{L}^{-1}$, considering the nature and proportion of the functional groups involved, the evolution with regards to the $\mathrm{pH}$ was quite similar to that observed in the previous experiment. Approximately $80 \%$ (from 78.8 to $86.7 \%$ ) of $\mathrm{Fe}(\mathrm{II})$ was bound to $\mathrm{HA}$ as bidentates (Fig. $4 \mathrm{a}$ ) and approximately $20 \%$ as tridentates. The proportions of Fe(II) bound as monodentates were insignificant $(<1 \%)$. At acidic $\mathrm{pH}$ (2.95 and 4.95), $66 \%$ of $\mathrm{Fe}(\mathrm{II})$ was bound to carboxylic groups, approximately $30 \%$ to carboxy-phenolic groups and approximately $1 \%$ to phenolic groups (Fig. $4 b$ ). At $\mathrm{pH}=6.93$, $52.3 \%$ of $\mathrm{Fe}(\mathrm{II})$ was bound to carboxy-phenolic groups, $33.5 \%$ to carboxylic groups and $14.2 \%$ to phenolic groups. At basic $\mathrm{pH}$ (8.89), Fe(II) was more bound to carboxy-phenolic groups $(59.6 \%)$, than to phenolic $(21.8 \%)$ or carboxylic groups $(18.6 \%)$. At acidic and neutral $\mathrm{pH}\left(\mathrm{pH} 2.95,4.95\right.$ and 6.93), $\mathrm{Fe}(\mathrm{II})$ was completely bound to $\mathrm{HA}$ as $\mathrm{Fe}^{2+}$ (Fig. 4c), whereas at basic $\mathrm{pH}(8.89), 6 \%$ of $\mathrm{Fe}(\mathrm{II})$ bound to $\mathrm{HA}$ occurred as $\mathrm{Fe}(\mathrm{OH})^{+}$.

\section{Discussion}

\subsection{Validation of the set of binding parameters}

Two strategies were used to validate the new estimated binding parameters (log $\mathrm{K}_{\mathrm{MA}}$ and $\left.\log \mathrm{K}_{\mathrm{MB}}\right)$. They were first compared with the parameters estimated by the LFER technique. Second, the conditions of the previously published experimental studies were put into PHREEQC-Model VI to calculate the expected Fe(II)-HS proportions; the calculated proportions were then compared with the proportions determined experimentally.

The binding parameters determined in the present work are different from those determined by Tipping (1998) due to (1) the deletion of the linear relationship between log $\mathrm{K}_{\mathrm{MA}}$ and $\log \mathrm{K}_{\mathrm{MB}}$ as performed by Marsac et al. (2011) and (2) the experimental dataset used for fitting. Tipping (1998) only used the criticized Van Dijk (1971) dataset. Van Dijk (1971) studied $\mathrm{Fe}(\mathrm{II})$ binding with $\mathrm{HA}$ through titrations and consequently only provided $\mathrm{pH}$ data. 
The specific log $\mathrm{K}_{\mathrm{MA}}$ and $\log \mathrm{K}_{\mathrm{MB}}$ parameters can be estimated using the linear relationship existing between these parameters and the acid acetic $\left(\log \mathrm{K}_{\mathrm{MA}}\right)$, first hydrolysis $\left(\log \mathrm{K}_{\mathrm{MA}}\right)$, and catechol $\left(\log \mathrm{K}_{\mathrm{MB}}\right)$ stability constants. The stability constant of $\mathrm{Fe}(\mathrm{II})$ with acetic acid $(\log \mathrm{K}(\mathrm{Fe}(\mathrm{II})-\mathrm{AA}))$ and the first hydrolysis constant of $\mathrm{Fe}^{2+}(\log \mathrm{K}(\mathrm{Fe}(\mathrm{II})-\mathrm{OH}))$ are $\log$ $\mathrm{K}(\mathrm{Fe}(\mathrm{II})-\mathrm{AA})=3.32$ and $\log \mathrm{K}(\mathrm{Fe}(\mathrm{II})-\mathrm{OH})=7.72$ (IUPAC). Using these values, the LFERs determined by Pourret et al. (2007) and Marsac et al. (2011) resulted in the following estimates for the $\log \mathrm{K}_{\mathrm{MA}}$ and $\log \mathrm{K}_{\mathrm{MB}}$ values: $1.57<\log \mathrm{K}_{\mathrm{MA}}<2.35$ (acetic acid LFER, $\mathrm{R}^{2}=$ 0.80 ) and $1.69<\log \mathrm{K}_{\mathrm{MA}}<2.65$ (first hydrolysis LFER, $\mathrm{R}^{2}=0.78$ ); $3.70<\log \mathrm{K}_{\mathrm{MB}}<4.09$ (catechol LFER, $R^{2}=0.95$ ). As can be seen, there is a full agreement between the log $K_{M A}$ value determined experimentally in this study (2.19) and the log $\mathrm{K}_{\mathrm{MA}}$ values estimated using the LEFR method. For log $\mathrm{K}_{\mathrm{MB}}$, the experimentally determined value (4.46) is bigger than the LFER estimate. However, the shift remains limited, as it was only $15 \%$.

An attempt to experimentally determine the binding constants of $\mathrm{Fe}$ (II) by FA was made by Schnitzer and Skinner (1966) using an ion-exchange method. Two sets of experiments were performed with the same concentration of $\mathrm{Fe}(\mathrm{II})\left(1.7910^{-3} \mathrm{~mol} \mathrm{~L}^{-1}\right)$ : one at pH 3.5 with $201,402,603,804$ and $1005 \mathrm{mg} \mathrm{L}^{-1}$ of $\mathrm{FA}$, and one at $\mathrm{pH}=5$ with $100.5,120.6$, 160.8, 201 and $241.2 \mathrm{mg} \mathrm{L}^{-1}$ of FA (Fig. 5). They showed that Fe(II) binding with FA was only slightly affected by pH. Schnitzer and Skinner's (1966) dataset was calculated using our new Fe(II)-HA binding parameters with PHREEQC-Model VI. For this purpose, we used the relationship between $\log \mathrm{K}_{\mathrm{MA}}(\mathrm{HA})$ and $\log \mathrm{K}_{\mathrm{MA}}(\mathrm{FA})$ established by Tipping (1998): log $\mathrm{K}_{\mathrm{MA}}(\mathrm{HA})=0.64{ }^{*} \log \mathrm{K}_{\mathrm{MA}}(\mathrm{FA})+0.79\left(\mathrm{R}^{2}=0.84\right)$. We also used this relationship to determine the binding parameters for $F A: \log K_{M A}=2.19 ; \log K_{M B}=4.46$ and $\Delta \mathrm{LK}_{2}=3.89$. At $p H=3.5$, the modeled partitioning of $\mathrm{Fe}(\mathrm{II})$ between free species and FA complexes was close to the experimental one, with a low RMSE value of 0.04 , but the fit was not as good at $\mathrm{pH}=5$ as the RMSE value was much higher (RMSE $=0.26$ ) (Fig. 5). Thus, the new set of binding parameters failed to reproduce Schnitzer and Skinner's data (1966) over the entire pH range. It is to be noticed, however, that Tipping (1998) himself did neither use Schnitzer and Skinner's (1966) dataset in his estimation of Fe(II)-FA binding parameters, nor for the other 
metals studied by these authors. Tipping and Hurley (1992) justified this by noting that the $\log \mathrm{K}_{\mathrm{MA}}$ value of $\mathrm{Fe}(\mathrm{II})-\mathrm{FA}$ calculated from Schnitzer and Skinner's (1966) dataset did not rank properly when compared to the log $\mathrm{K}_{\mathrm{MA}}$ values determined for the other cations. The $\mathrm{Fe}$ (II) log $\mathrm{K}_{\mathrm{MA}}$ obtained using Schnitzer and Skinner's (1966) dataset was intermediate between $\mathrm{Pb}^{2+}$ and $\mathrm{Cu}^{2+} \log \mathrm{K}_{\mathrm{MA}}$, in contradiction with the findings of Martell and Smith (1977), who established that $\mathrm{Fe}^{2+}$ stability constants should be lower than those for $\mathrm{Pb}^{2+}$ and $\mathrm{Cu}^{2+}$ binding constants with mono- and di-carboxylic acids. This dataset was also criticized by Milne et al. (2003) who attributed it a poor score when trying to fit it using the NICA-Donnan model. They could not simply extrapolate the calculated data from Schnitzer and Skinner's (1966) experimental data and had to constrain the second site distribution values using LFER between their binding parameters and log $\mathrm{KOH}$. According to Tipping and Hurley (1992) it is possible that in the experimental conditions used by Schnitzer and Skinner (1966), part of the $\mathrm{Fe}(\mathrm{II})$ was oxidized into $\mathrm{Fe}(\mathrm{III})$, and that this oxidation caused the observed shift between the calculated and expected log $\mathrm{K}_{\mathrm{MA}}$ values.

Yamamoto et al. (2010) estimated the binding capacities of HS with $\mathrm{Fe}(\mathrm{II})$ using a colorimetric method. Yamamoto et al. (2010) used HA and FA extracted from compost with a $\mathrm{HA}$ concentration of $1 \mathrm{mg} \mathrm{L}^{-1}$ and determined the $\mathrm{Fe}(\mathrm{II})$ concentrations using the ferrozine colorimetric method. As with Schnitzer and Skinner's (1966) data, the new binding parameters obtained here failed to model these data (RMSE $>1$ ). This failure is thought to be due to an analytical bias in the dataset, related to the colorimetric method. Jackson et al. (2012) emphasized the poor reliability of the colorimetric methods to determine the $\mathrm{Fe}(\mathrm{II})$ concentration bound to HS.

Rose and Waite (2003) studied the kinetics of Fe(II) complexation with NOMs. They used 12 different NOMs recovered from the soil leaf litter layer and one fulvic acid stock solution: Suwannee River FA (SRFA). Binding experiments were performed in seawater with a nominal salinity of 36 (ionic strength $\approx 1.7 \mathrm{M}$ ) at $\mathrm{pH} 8.1$. Three $\mathrm{Fe}(\mathrm{II})$ concentrations were used: $0.25,0.5$ and $1 \mu \mathrm{mol} \mathrm{L}^{-1}$ with a total organic carbon concentration of $1 \mathrm{mg} \mathrm{L}^{-1}$. All of the data used for the calculations were equilibrium concentrations (i.e. concentrations 
determined at the end of the kinetics). The amount of $\mathrm{Fe}(\mathrm{II})$ adsorbed at equilibrium differed from one NOM to another. For example, for $[\mathrm{Fe}(\mathrm{II})]_{\text {tot }}=1 \mu \mathrm{mol} \mathrm{\textrm {L } ^ { - 1 }}$, the percentages of experimentally adsorbed Fe(II) varied from 5 to $100 \%$ depending on the NOM sample considered. This variability could not be reproduced by PHREEQC-Model VI (Fig. 6a), suggesting that some important properties of the NOM samples used were not taken into account by the model. In fact, the NOM samples used by Rose and Waite (2003) in their experiments were extracted from soil leaf litter, which were probably different in composition from the HS structure considered in PHREEC-Model VI. The situation is obviously much different for the SRFA sample used by Rose and Waite (2003), which has a structure that is typical for a HS. Interestingly, a reasonably good fit $(\mathrm{RMSE}=0.03)$ was obtained with the new binding parameters for the data (SRFA) published by Rose and Waite (2003) (Fig. 6b). Note that data from Van Dijk's dataset (1971) were not used for the purpose of a validation test considering, as Milne et al. (2003) did, that the measurement of the $\mathrm{pH}$ values was not sufficiently precise in this study.

Thus the new binding parameters obtained here were able to model the $\mathrm{Fe}(\mathrm{II})$ adsorption onto both HA and FA reasonably well. The new set of parameters satisfactorily reproduced Rose and Waite's (2003) experimental data for SRFA (RMSE $=0.03$ ) and the present data. It is interesting to see that previously determined binding parameters used a linear relationship between $\log \mathrm{K}_{\mathrm{MA}}$ and $\log \mathrm{K}_{\mathrm{MB}}$ (Tipping, 1998). In fact, the present data cannot be modeled if this relationship is imposed. As Marsac et al. (2012) did, we had to remove this constraint to satisfactorily model our data. When Marsac et al. (2012) tried to model their data using the linear relationship, REE patterns were identical for weak and strong sites, which is impossible with regards to their stability constants with single organic ligands, such as acetate (weak sites) or EDTA (strong sites) (Marsac et al., 2011). To reproduce correctly REE patterns binding to strong sites, the authors had to delete this linear relationship. Consequently, $\log \mathrm{K}_{\mathrm{MB}}$ values decreased and were compensated by higher values of $\Delta \mathrm{LK}_{2 \mathrm{C}}$ and $\Delta \mathrm{LK}_{2 \mathrm{p}}$. Most likely, this explains why we also obtained a high $\Delta \mathrm{LK}_{2}$ value (3.90). Despite the use of a glovebox, part of the $\mathrm{Fe}$ (II) might be oxidized into $\mathrm{Fe}$ (III) which 
might explain the strong $\mathrm{Fe}$ adsorption at acidic $\mathrm{pH}$ and the subsequent high value of $\Delta \mathrm{LK}_{2}$. However, humic substances are expected to delay the oxidation of Fe (Wolthoorn et al., 2004; Kleber et al., 2005; Weber et al., 2006; Miller et al., 2009) and no Fe(III) was measured in the ultrafiltrated solution. Indeed, Weber et al. (2006) performed sorption experiments of $\mathrm{Fe}(\mathrm{III})(50$ and $30 \mu \mathrm{M})$ with organic matter $\left(1.8 \mathrm{~g} \mathrm{~L}^{-1}\right)$. They showed that for the lowest total Fe concentrations, a fraction of Fe can be reduced by humic substances. The concentrations of $\mathrm{Fe}(\mathrm{II})$ used in the present study were from 11 to $56 \mu \mathrm{M}$, within the range of Weber et al.'s (2006) experiments. Weber et al.'s (2006) study suggests therefore that OM tends to reduce $\mathrm{Fe}(\mathrm{III})$ into $\mathrm{Fe}(\mathrm{II})$ and not to oxidize it. So, oxidation of $\mathrm{Fe}(\mathrm{II})$ into $\mathrm{Fe}(\mathrm{III})$ seems unlikely in the experimental conditions used in the present study.

However at any rate, the high $\Delta \mathrm{LK}_{2}$ value obtained here is lower than the $\Delta \mathrm{LK}_{2}$ of 4.0 reported by Marsac et al. (2012; 2013) for the binding of $\mathrm{Fe}(\mathrm{III})$ by $\mathrm{HS}$ (Table 2), which is rather consistent given that $\mathrm{Fe}(\mathrm{III})$ species are known to form stronger complexes with HS than $\mathrm{Fe}$ (II) species (Ou et al., 2009). The new binding parameters determined in the present study $\left(\log \mathrm{K}_{\mathrm{MA}}=2.19, \log \mathrm{K}_{\mathrm{MB}}=4.46\right.$ and $\left.\Delta \mathrm{LK}_{2}=3.90\right)$ are therefore in accordance with the $\mathrm{Fe}(\mathrm{III})$ binding parameters of Marsac et al. (2013).

\subsection{Fe(II) speciation onto $H A$ binding sites}

Although several extended X-ray absorption fine structure (EXAFS) analyses concerning the binding of Fe to OM have been performed for Fe(III) (Gustafsson et al., 2007; Van Schaik et al., 2008; Morris et al., 2012), no spectroscopic data are currently available for $\mathrm{Fe}(\mathrm{II})-\mathrm{OM}$ binding. Therefore, the validation of the speciation results obtained here for $\mathrm{Fe}(\mathrm{II})-$ HS binding using PHREEQC-Model VI can only be achieved through comparison with the case of $\mathrm{Fe}(\mathrm{III})$. Gustafsson et al. (2007) analyzed the binding of $\mathrm{Fe}(\mathrm{III})$ to organic soils using EXAFS spectroscopy. They determined that Fe(III) bound to organic soils seems to occur through dimeric and trimeric complexes, where Fe ions are connected by $\mu$-oxo bridges. Using scanning electron microscopy (SEM) images, Ou et al. (2009) suggested that Fe(III) is 
bound to HA as oligomeric species (not as single ions). These results differ from the EXAFS studies performed on the binding of Fe(III) with FA (Van Schaik et al., 2008), peat humic acid (Karlsson et al., 2010) and organic soils (Karlsson et al., 2010), which have shown the formation of mononuclear complexes between $\mathrm{Fe}(\mathrm{III})$ and organic functional groups. This reveals that mononuclear Fe species are likely the dominant species involved in the binding of $\mathrm{Fe}$ (III) by HS. The PHREEQC-Model VI binding hypothesis considers that Fe(II) is bound to HS as mononuclear species, which appears consistent with the spectroscopic data obtained for Fe(III). Moreover, Gustafsson et al. (2007), Van Schaik et al. (2008) and Morris and Hesterberg (2012) suggested that the functional groups involved in the binding of $\mathrm{Fe}(\mathrm{III})$ are phenolate and carboxylate groups, while Weber et al. (2006) argued for a dominant role of carboxylic groups. They tested two models for $\mathrm{Fe}(\mathrm{III})-\mathrm{HA}$ binding with or without a contribution from the phenolic groups. With phenolic groups, the adsorbed $\mathrm{Fe}(\mathrm{III})$ with phenolate was negligible. Using Fourier transform infrared spectroscopy (FTIR), Ou et al. (2009) suggested that Fe(III) is mainly bound to HA carboxylate and carboxylic groups via monodentate and bidentate sites, whereas binding with HA phenolate and carboxy-phenolate groups would occur mainly through monodendate and bidendate sites, respectively. The results of the modeling calculations performed in this study indicated that $\mathrm{Fe}(\mathrm{II})$ could bind to HA by carboxylic and phenolic groups as suggested by Gustafsson et al. (2007), Van Schaik et al. (2008) and Morris and Hesterberg (2012) for Fe(III). Moreover, modeling calculations revealed that $\mathrm{Fe}(\mathrm{II})$ was bound with $\mathrm{HA}$ mainly through bidentate complexes with a subordinate participation of tridentate sites. At basic to neutral $\mathrm{pH}, \mathrm{Fe}(\mathrm{II})$ was bound to carboxylic groups, which is consistent with the results obtained for $\mathrm{Fe}(\mathrm{III})$ by Weber et al. (2006) and Ou et al. (2009). By contrast, as suggested by Ou et al. (2009) for Fe(III), Fe(II) was mainly bound to carboxy-phenolic groups. 


\subsection{Environmental implications}

These new data provided the assessment that Fe(II) could be strongly bound to HA. Iron(II) complexation with $\mathrm{HA}$ or $\mathrm{OM}$ therefore put strong constraints on the observed dissolved $\mathrm{Fe}(\mathrm{II})$ concentrations and the possible transfer of $\mathrm{Fe}(\mathrm{II})$ within waters and hydrosystems enriched in OM. For example, in a coastal environment, Fe occurs mainly as insoluble Fe-oxyhydroxides (Rose and Waite, 2003). Bioavailable Fe is therefore relatively scarce in such environments. However, any $\mathrm{Fe}(\mathrm{II})$ binding by $\mathrm{OM}$ can largely increase its solubility by preventing its hydrolysis/oxidation, therefore forming mobile soluble organic complexes (Rose and Waite, 2003; Miller et al., 2009; 2012). These studies showed that $\mathrm{Fe}(\mathrm{II})-\mathrm{OM}$ binding forms strong complexes, which can have a significant effect on its solubility in coastal waters.

Another major environmental implication concerns the behavior of $\mathrm{Fe}(\mathrm{II})$ within wetlands. When reductive conditions develop in wetlands during the flooding season, high amounts of dissolved Fe(II), DOC and trace elements can be released in the soil solution (Ponnamperuma, 1972; McBride, 1994; Dia et al., 2000; Olivié-Lauquet et al., 2001). In such conditions, with regards to the strong affinity of $\mathrm{Fe}(\mathrm{II})$ for $\mathrm{OM}, \mathrm{Fe}(\mathrm{II})$ will be mainly bound to DOC thus preventing its precipitation as a secondary mineral such as magnetite or green rust. As the formation of Fe-rich secondary minerals is limited, Fe-associated trace elements are not taken up and thereby remain highly mobile. Such processes have been previously suggested by Davranche et al. (2013) from kinetic modeling. These authors showed that organic-mediated $\mathrm{Fe}(\mathrm{II})$ complexation is a major controlling factor of Fe reactivity in wetland soils.

Moreover, the presence of other cations can change the quantities of $\mathrm{Fe}$ (II) bound to $\mathrm{HA}$. The values of the binding parameters for some cations (e.g. $\mathrm{Mg}(\mathrm{II}), \mathrm{Ca}(\mathrm{II}), \mathrm{Mn}(\mathrm{II}), \mathrm{Co}(\mathrm{II})$, $\mathrm{Ni}(\mathrm{II}), \mathrm{Zn}(\mathrm{II}), \mathrm{Sr}(\mathrm{III}), \mathrm{Cd}(\mathrm{II}), \mathrm{Ba}(\mathrm{II}))$ are smaller than those of $\mathrm{Fe}(\mathrm{II})$, which means that the presence of these cations would only have minor consequences on the quantities of $\mathrm{Fe}(\mathrm{II})$ bound to HA or FA. By contrast, some other cations (Al(III), $\mathrm{Cr}(\mathrm{III}), \mathrm{Fe}(\mathrm{III}), \mathrm{Pb}(\mathrm{II}), \mathrm{REE})$ have 
binding parameters values that are higher than those of $\mathrm{Fe}(\mathrm{II})$ and can therefore strongly compete with $\mathrm{Fe}(\mathrm{II})$ for $\mathrm{HA}$ binding if they are present in sufficient concentrations.

Finally, several authors have shown that Fe(III), through the formation of ternary complexes with HS, allows the binding of $\mathrm{As}(\mathrm{V})$ as oxyanion to OM (Sharma et al., 2010) and HS (Mikutta et al., 2011). In anoxic environments, as Fe(II) is the dominant species, such ternary associations are thus expected to be formed binding $\mathrm{Fe}(\mathrm{II}), \mathrm{HS}$ and $\mathrm{As}(\mathrm{III})$ or $\mathrm{As}(\mathrm{V})$. In this context, the present study and the new set of binding parameters suggested that such ternary associations with Fe(II) may be relatively important in wetlands and floodplains. Thus these data constitute a first step for studying the formation of a cationic bridge between As(III, V), Fe(II) and HA and therefore the involved processes controlling As mobility at the soil-water interface within organic-rich environments undergoing redox alternations.

\section{Conclusions}

Iron(II) adsorption experiments onto humic acid (HA) were designed to study the binding of $\mathrm{Fe}(\mathrm{II})$ by organic matter. The experimental results showed that $\mathrm{Fe}(\mathrm{II})$ was strongly bound to HA as previously observed by several authors (Schnitzer et al., 1966; Van Dijk, 1971; Tipping, 1998; Rose and Waite, 2003; Yamamoto et al., 2010). Coupling PHREEPLOT and PHREEQC-Model VI, a new set of specific binding parameters was calculated for Fe(II)$\mathrm{HA}$ complex $\left(\log \mathrm{K}_{\mathrm{MA}}=2.19 \pm 0.16, \log \mathrm{K}_{\mathrm{MB}}=4.46 \pm 0.47\right.$ and $\left.\Delta \mathrm{LK}_{2}=3.90 \pm 1.31\right)$. These binding parameters are higher than those previously calculated by Tipping (1998) using only Van Dijk's dataset (1971). The new set of Fe(II)-HA binding parameters was used to test and validate the model using the relationship between the HA and FA parameters. They reasonably reproduced Rose and Waite's data (2003) on the adsorption kinetics of Fe(II) with SRFA. The RMSE between the calculated and experimental data was low (0.03), validating the newly determined set of binding parameters as well as the experimental and modeling approaches used in this study. This new dataset of binding parameters implies a higher complexation between $\mathrm{Fe}(\mathrm{II})$ and humic substances than that previously suggested, and 
shows that $\mathrm{OM}$ is of major importance in the fate and bioavailability of $\mathrm{Fe}(\mathrm{II})$ and possibly associated trace metals such as As within the environment. 


\section{References}

AFNOR, 1982 Essais des eaux - Dosage du fer - Méthode spectrométrique à la phénantroline-1,10. AFNOR, Paris.

Bauer, M., Blodau, C., 2006. Mobilization of arsenic by dissolved organic matter from iron oxides, soils and sediments. Sci. tot. Environ. 354, 179-190.

Buffle, J., Wilkinson, K. J., Stoll, S., Filella, M., Zhang, J. W., 1998. A generalized description of aquatic colloidal interactions: the three-colloidal component approach. Environ. Sci.Technol. 32, 2887-2899.

Buffle, J., De Vitre, R.R., Perret, D., Leppard G.G., 1989. Physico-chemical characteristics of a colloidal iron phosphate species formed at the oxic-anoxic interface of a eutrophic lake. Geochim. Cosmochim. Acta. 53, 399-408.

Buschmann, J., Kappeler, A., Lindauer, U., Kistler, D., Berg, M., Sigg, L., 2006. Arsenite and Arsenate Binding to Dissolved Humic Acids: Influence of pH, Type of Humic Acid, and Aluminium. Environ. Sci. Technol. 40, 6015-6020.

Buschmann, J., Sigg, L., 2004. Antimony(III) Binding to Humic Substances: Influence of pH and Type of Humic Acid. Environ. Sci. Technol. 38, 4335-4541.

Christl, I., Knicker, H., Kogel-Knabner, I., Kretzschmar, R., 2000. Chemical heterogeneity of humic substances: characterization of size fractions obtained by hollow-fibre ultrafiltration. Eur. J. of Soil Sci. 51, 617-625.

Davison, W., 1993. Iron and manganese in lakes. Earth-Science Reviews, 34, 119-163.

Davranche, M., Dia, A., Fakih, M., Nowack, B., Gruau, G., Ona-Nguema, G., Petitjean, P., Martin, S., Hochreutener, R., 2013. Organic matter control on the reactivity of Fe(III)oxyhydroxides and associated As in wetland soils: A kinetic modeling study. Chem. Geol. $335,24-35$.

Dia, A., Gruau, G., Olivié-Lauquet, G., Riou, C., Molénat, J., 2010. The distribution of rare earth elements in groundwaters: assessing the role of source-rock composition, redox changes and colloidal particles. Geochim. Cosmochim. Acta. 64, 4131-4151. 
Emmenegger, L., Schonenberger, R., Sigg, L., Sulzberger, B., 2001. Light-induced redox cycling of iron in circumneutral lakes. Limnol. and Oceanogr. 46, 49-61.

Evangelou, V., Marsi, M., 2001. Composition and metal ion complexation behavour of humic fractions derived from corn tissue. Plant and Soil. 229, 13-24.

Fendorf, S., Nico, P. S., Kocar, B. D., Masue, Y., Tufano, K. J., 2010. Arsenic Chemistry in Soils and Sediments. Developments in Soil Science 34, 357-378.

Filella, M., Williams, P. A., 2012. Antimony interactions with heterogeneous complexants in waters, sediments ans soils: A review of binding data for homologous compounds. Chemie der Erde. 72, 49-65.

Fujisawa, N., Furubayashi, K., Fukushima, M., Yamamoto, M., Komai, T., Ootsuka, K., Kawabe, Y., 2011. Evaluation of the Iron(II)-binding Abilities of Humic Acids by Complexometric Titration using Colorimetry with ortho-Phenanthroline. Humic Substances Research. 8. 1-6.

Fukushima, M., Tanaka, S., Nakamura, H., Ito, S., Haraguchi, K., Ogata, T., 1996. Copper(II) binding abilities of molecular weight fractionated humic acids ans their mixtures. Anal. Chim. Acta. 322, 173-185.

Fukushima, M., Hasebe K., Taga, M., 1992. Effect of sodium dodecyl sulfate on the measurement of labile copper(II) species by anodic stripping voltammetry in the presence of humic acid. Anal. Chim. Acta. 270, 153-159.

Fukushima, M., Fujisawa, N., Furubayashi, K., Iwai, H., Otsuka, K., Yamamoto, M., Komai, T., Kawabe, Y., Horiya, S., 2012. Structural Features and Fe(II)-Binding Capacities of Humic Acids from Reservoir Sediments. Journal of Chemical Engineering of Japan. 45, $452-458$.

Gustafsson, J. P., Persson, I., Kleja, D. B., Van Schaik, J. W., 2007. Binding of Iron(III) to Roganics Soils: EXAFS Spectroscopy and Chemical Equilibrium Modeling. Environ. Sci. Technol. 41, 1232-1237. 
Harvey, C. F., Ashfaque, K. N., Yu, W., Badruzzaman, A. B. M., Ali, M. A., Oates, P. M., Michael, H. A., Neumann, R. B., Beckie, R., Islam, S., Ahmed, M. F., 2006. Groundwater dynamics and arsenic contamination in Bangladesh. Chem. Geol. 228, 112-136.

IUPAC IUPAC Stability Constants Database. Version 5.85, IUPAC and Academic 584 Software (acadsoft@bcs.org.uk) [Livre].

Jackson, A., Gaffney, J. W., Boult, S., 2012. Subsurface Interactions of Fe(II) with Humic Acid or Landfill Leachate Do Not Control Subsequent Iron(III) (Hydr)oxide Production at the Surface. Environ. Sci. Technol. 46, 7543-7550.

Kar, S., Maity, J. P., Jean, J. S., Liu, C. C., Nath, B., Lee, Y. C., Bundschuh, J., Chen, C. Y., Li, Z., 2011. Role of organic matter and humic substances in the binding and mobility of arsenic in a Gangetic aquifer J. Environ. Res. Public Health. 46, 1231-1238.

Karlsson, T., Persson, P., Skyllberg, U., Mörth, C.-M., Giesler, R., 2008. Characterization of Iron(III) in Organic Soils Using Extended X-ray Absorption Fine Structure Spectroscopy. Environ. Sci.Technol. 42, 5449-5454.

Karlsson, T., Persson, P., 2010. Coordination chemistry and hydrolysis of $\mathrm{Fe}(\mathrm{III})$ in a peat humic acid studied by X-ray absorption spectroscopy. Geochim. Cosmochim. Acta. 74, $30-40$.

Kocar, B. D., Polizzotto, M. L., Benner, S. G., Ying, S. C., Ung, M., Ouch, K., Samreth, S., Suy, B., Phan, K., Sampson M., Fendorf, S., 2008. Integrated biogeochemical and hydrologic processes driving arsenic release from shallow sediments to groundwaters of the Mekong delta. Appl. Geochem. 23, 3059-3071.

Lin, H. T., Wang, M. C., Li, G. C., 2004. Complexation of arsenate with humic substance in water extract of compost. Chemosphere. 56, 1105-1112.

Liu, G., Cai, Y., 2010. Complexation of arsenite with dissolved organic matter: Conditional distribution coefficients and apparent stability constants. Chemosphere. 81, 890-896.

Marsac, R., Davranche, M., Gruau, G., Dia, A., Bouhnik-Le Coz M., 2012. Aluminium competitive effect on rare earth elements binding to humic acid. Geochim. Cosmochim. Acta. 89, 1-9. 
Marsac, R., Davranche, M., Gruau, G., Bouhnik-Le Coz, M., Dia, A., 2011. An improved description of the interactions between rare earth elements and humic acids by modeling: PHREEQC-Model VI coupling. Geochim. Cosmochim. Acta. 75, 5625-5637.

Marsac, R., Davranche, M., Gruau, G., Dia, A., Pédrot, M., Le Coz-Bouhnik, M., Briant, N. 2013. Effects of Fe competition on REE binding to humic acid: Origin of REE pattern variability in organic waters. Chem. Geol. 342, 119-127.

Martell, A. E., Smith, R. M., 1976, 1977. Critical stability constants, New York ; London : Plenum Press, 4 Inorganic complexes, 257.

McBride M.B., 1994. Environmental Chemistry of Soils. New York,Oxford University Press.

Mikutta, C., Kretzschmar, R., 2011. Spectroscopic Evidence for Ternary Complex Formation between Arsenate and Ferric Iron Complexes of Humic Substances. Environ. Sci. Technol. 45, 9550-9557.

Miller, C. J., Lee, S. M. V., Rose, A. L., Waite, T. D., 2012. Impact of Natural Organic Matter on H2O2-Mediated Oxidation of Fe(II) in Coastal Seawaters. Environ. Sci. Technol. 46, 11078-11085.

Miller, C. J., Rose, A. L., Waite, T. D., 2009. Impact of natural organic matter on $\mathrm{H}_{2} \mathrm{O}_{2}-$ mediated oxidation of $\mathrm{Fe}(\mathrm{II})$ in a simulated freshwater system. Geochim. Cosmochim. Acta. $73,2758-2768$.

Milne, C. J., Kinniburgh, D. G., Van Riemsdijk, W. H., Tipping, E., 2003. Generic NICADonnan Model Parameters for Metal-Ion Binding by Humic Substances. Environ. Sci. Technol. 37, 958-971.

Morris, A. J., Hesterberg, D. L., 2012. Iron(III) Coordination and Phosphate Sorption in Peat Reacted with Ferric or Ferrous. Iron Soil Sci. Soc. Am. J. 76, 101-109.

Mota, A. M., Pinheiro, J., Gonçalves, M. L., 1994. Adsorption of humic acid on a mercury/aqueous solution interface. Wat. Res. 28, 1285-1296.

Nuzzo, A., Sánchez, A., Fontaine, B., Piccolo, A., 2013. Conformational changes of dissolved humic and fulvic superstructures with progressive iron complexation. J. Geochem. Explor. 129, 1-5. 
Olivié-Lauquet, G., Gruau, G., Dia, A., Riou, C., Jaffrezic A., Henin, O., 2001. Release of trace elements in wetlands: Role of seasonal variability. Water Res. 35, 943-952.

Ou, X., Chen, S., Quan, X., Zhao, H., 2009. Photochemical activity and characterization of the complex of humic acids with iron(III). J. Geochem. Explor.102, 49-55.

Pédrot, M., Le Boudec, A., Davranche, M., Dia, A., Henin, O., 2011. How does organic matter constrain the nature, size and availability of $\mathrm{Fe}$ nanoparticles for biological reduction? J. Colloid Interf. Sci. 359, 75-85.

Piccolo, A., 1988. Characteristics of soil humic substances extracted with some organic and inorganic solvents and purified by the HCl-HF treatment. Soil Science 146, 418-426.

Piccolo A, 1996. Humus and Soil Conservation, in: Piccilo, Humic Substances in Terrestrial Ecosystems. Amsterdam: Elsevier. 225-264.

Piccolo, A., Nardi, S., Concheri, G., 1996. Macromolecular changes of humic substances induced by interaction with organic acids. Eur. J. of Soil Sci. 47, 319-328.

Pilarski, J., Waller, P., Pickering, W., 1995 Sorption of antimony species by humic acid Wat. Air Poll. 84, 51-59.

Pinheiro, J., Mota, A. M., Gonçalves, M. L. S., 1994 Complexation study of humic acids with cadmium (II) and lead (II). Anal. Chim. Acta 284, 525-537.

Polizzotto, M. L., Kocar, B. D., Benner, S. G., Sampson M., Fendorf, S., 2008. Near-Surface wetland sediments as a source of arsenic release to ground water in Asia. Nature. 454, 505-509.

Ponnamperuma F., 1972. The chemistry of submerged soils. Advances in Agronomy. 24, 2996.

Pourret, O., Davranche, M., Gruau, G., Dia, A., 2007. Organic complexation of rare earth elements in natural waters: Evaluating model calculations from ultrafiltration data. Geochim. Cosmochim. Acta 71, 2718-2735.

Pullin, M. J., Cabaniss, S. E., 2003. The effects of pH, ionic strength, and iron-fulvic acid interactions on the kinetics of non-photochemical iron transformations. I. Iron(II) oxidation and iron(III) colloid formation. Geochim. Cosmochim. Acta. 67, 4067-4077. 
Pullin, M. J., Cabaniss, S. E., 2003. The effects of $\mathrm{pH}$, ionic strength, and iron-fulvic acid interactions on the kinetics of non-photochemical iron transformations. II. The kinetics of thermal reduction. Geochim. Cosmochim. Acta. 67, 4079-4089.

Reddy, K. J., PAtrick, W.H., 1977.Effect of Redox Potential and $\mathrm{pH}$ on the Uptake of Cadmium and Lead Products in Soil. Soil Sci. Soc. Am. J. 54, 67-71.

Redman, A. D., Macalady, D. L., Ahmann, D., 2002. Natural Organic Matter Affects Arsenic Speciation and Sorption onto Hematite. Environ. Sci. Technol. 36, 2889-2896.

Ritter, K., Aiken, G. R., Ranville, J. F., Bauer, M., Macalady, D. L., 2006. Evidence for Aquatic Binding of Arsenate by Natural Organic Matter-Suspended Fe(III). Environ. Sci. Technol. 40, 5380-5387.

Rose, A. L., Waite, T. D., 2003. Kinetics of iron complexation by dissolved natural organic matter in coastal waters. Mar. Chem. 84, 85-103.

Schnitzer, M., Skinner, S., 1966. Organo-metallic interactions in soils: 5. Stability constants of Cu++-, Fe++-, and Zn++-Fulvic Acid Complexes. Soil Science. 102, 361-365.

Sharma, P., Ofner, J., Kappler, A., 2010. Formation of Binary and Ternary Complexes of Organic Matter, Fe, As. Environ. Sci. Technol. 44, 4479-4485.

Sposito, G., 1986. Sorption of trace-metals by humic materials in soils and natural-waters. CRC Critical Reviews in Environmental Control. 16, 193-229.

Tella, M., Pokrovski, G. S., 2009. Antimony(III) complexing with O-bearing organic ligands in aqueous solution :an X-ray absorption fine structure spectroscopy and solubility study. Geochim. Cosmochim. Acta 73, 268-290.

Thanabalasingam, P., Pickering, W. F., 1986. Arsenic Sorption by Humic Acids Environ.Poll. 12 (Series B), 233-246.

Tighe, M., Lockwood, P., Wilson, S., 2005. Adsorption of antimony(V) by floodplain soils, amorphous iron(III) hydroxide and humic acid. J. Environ. Monit. 7, 1177-1185.

Tipping, E., 2002. Cation binding by humic substances. Cambridge Environmental Chemistry Series 12. 
Tipping, E., Hurley, M., 1992. A unifying model of cation binding by humic substances. Geochim. Cosmochim. Acta. 56, 3627-3641.

Tipping, E., 1998. Humic Ion-Binding Model VI: An Improved Description of the Interactions of Protons and Metal lons with Humic Substances. Aq. Geochem. 4, 3-48.

Town, R. M., Powell, K. J., 1993. Ion-selective electrode potentiometric studies on the complexation of copper(II) by solid-derived humic and fulvic acids. Anal. Chim. Acta 279, 221-233.

Van Dijk, H, 1971. Cation Binding Humic Acids. Geoderma. 5, 53-67.

Van Schaik, J. W., Persson, I., Kleja, D. B., Gustafsson, J. P., 2008. EXAFS Study on the Reactions between Iron and Fulvic Acid in Acid Aqueous Solutions. Environ. Sci. Technol. 42, 2367-2373.

Warwick, P., Inam, E., Evans, N., 2005. Arsenic's Interaction with Humic Acid. Envi. Chem. $2,119-124$

Weber, T., Allard, T., Tipping, E., Benedetti, M. F., 2006. Modeling Iron Binding to Organic Matter. Environ. Sci. Technol. 40, 7488-7493.

Yamamoto, M., Nishida, A., Otsuka, K., Komai, T., Fukushima, M., 2010. Evaluation of the binding of iron(II) to humic substances derived from a compost sample by colorimetric method using ferrozine. Bioresour. Technol. 101, 4456-4460. 


\section{Figures:}

As each experiment was performed in triplicate, each point represents the average of the triplicates. The error bars represent the standard deviation (in log or percentage, depending on the data) calculated from the triplicated experimental data.

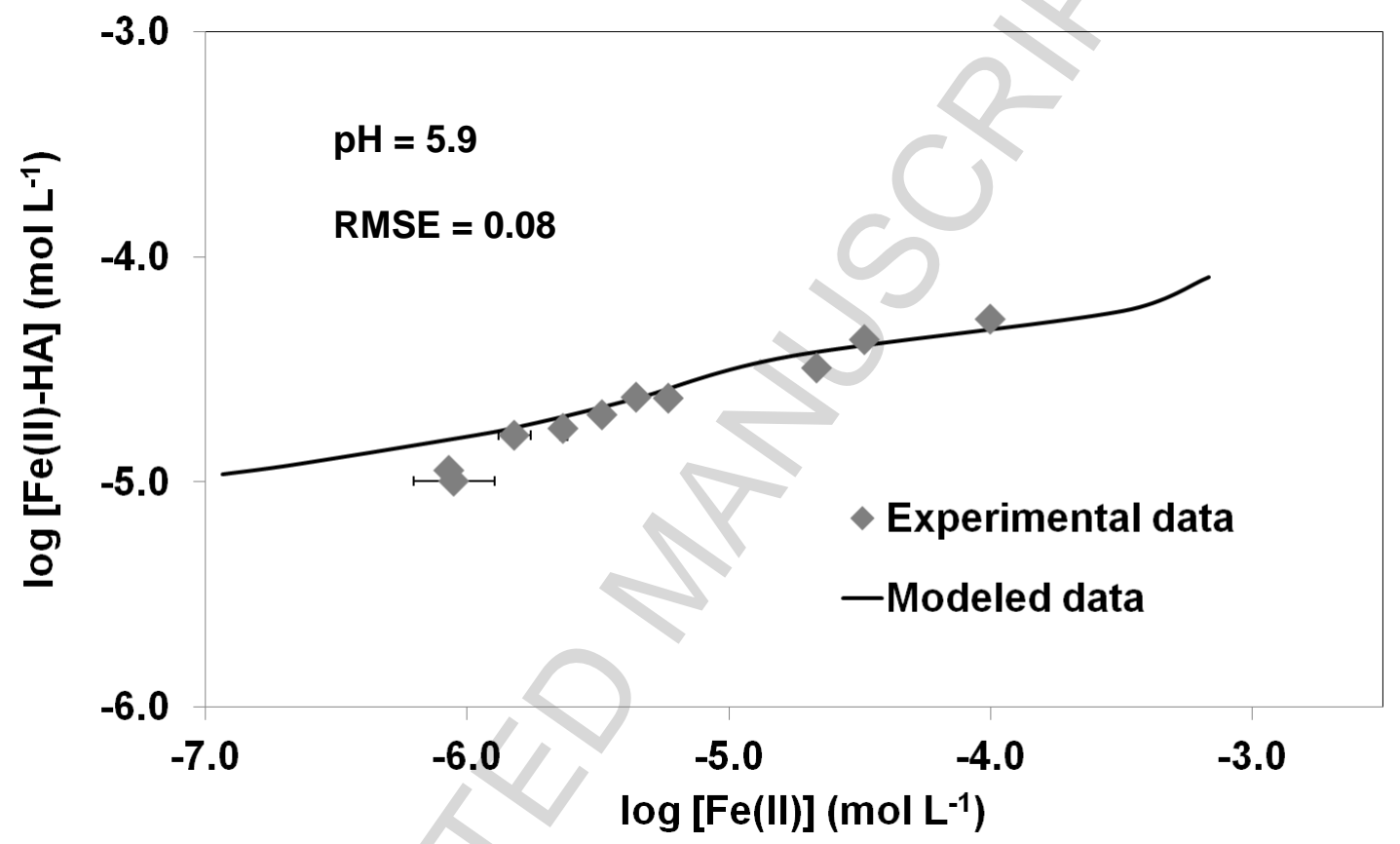

(a)

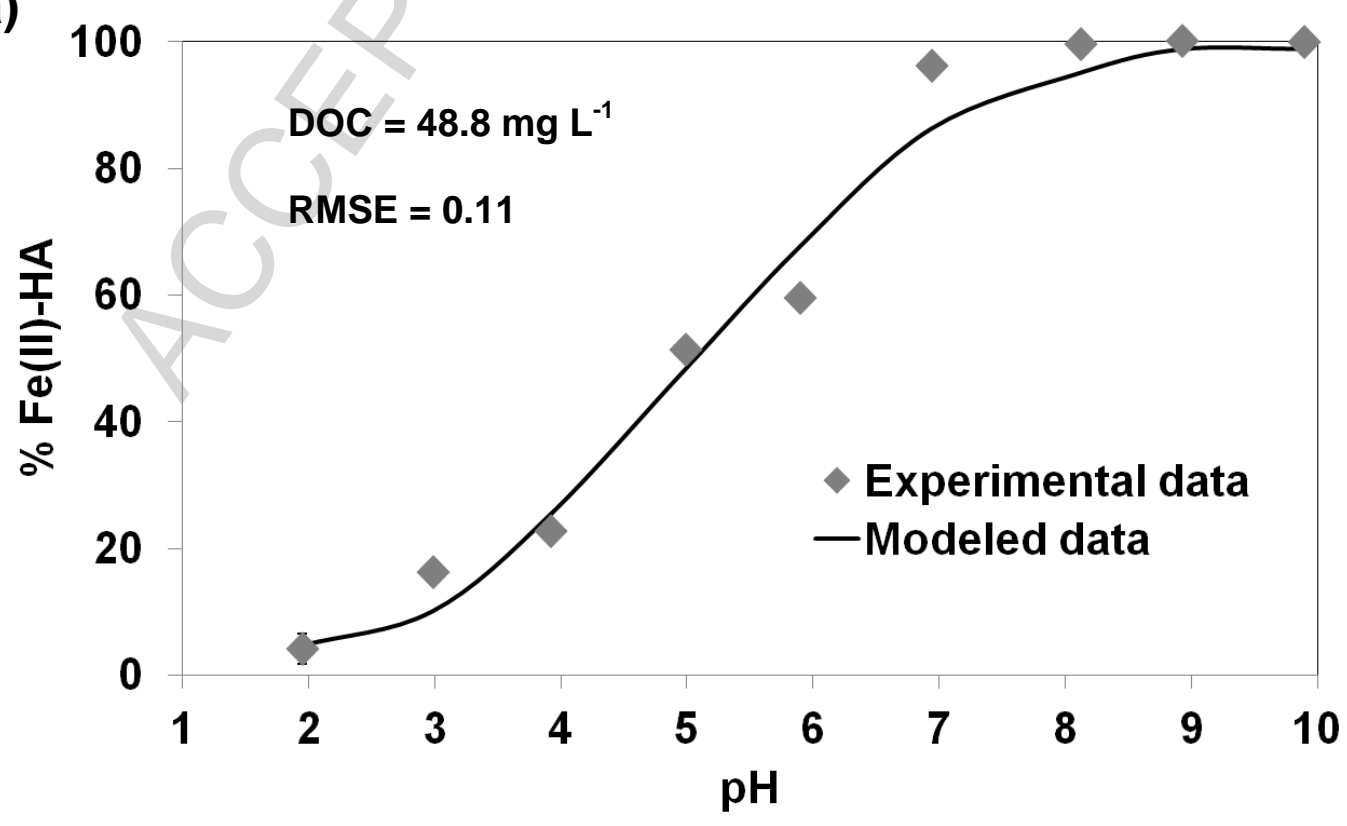

(b) 


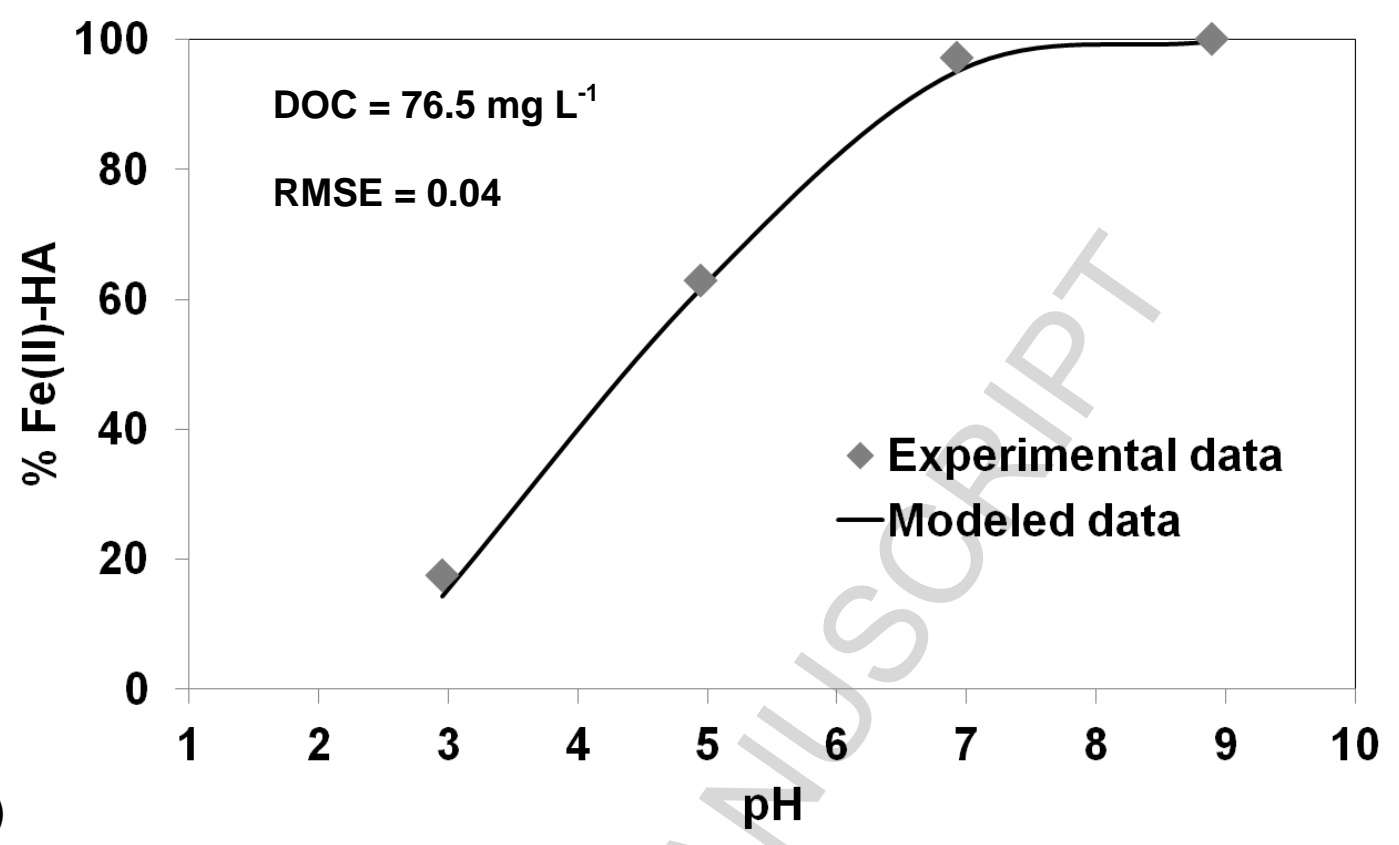

Fig. 1: (a) Adsorption isotherm: experimental and modeled data, (b) $\mathrm{pH}$ adsorption edge - $\mathrm{DOC}=50 \mathrm{mg} \mathrm{L}^{-1}$ (c) $\mathrm{pH}$ adsorption edge $-\mathrm{DOC}=76 \mathrm{mg} \mathrm{L}^{-1}$ (the error bars calculated from the triplicated experiments are within the symbols.). 


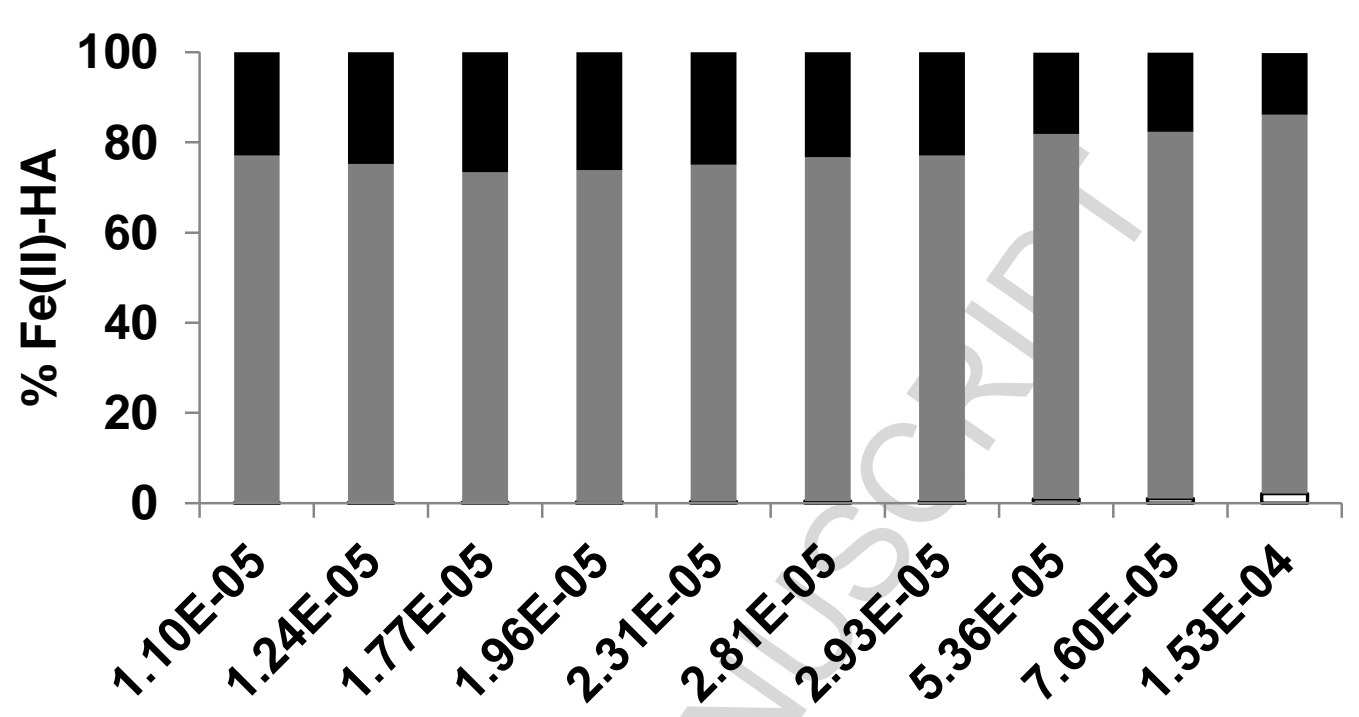

(a)

$[\mathrm{Fe}(\mathrm{II})]_{\text {tot }}\left(\mathrm{mol} \mathrm{L}^{-1}\right)$

$\square$ Monodentates Bidentates $\square$ Tridentates

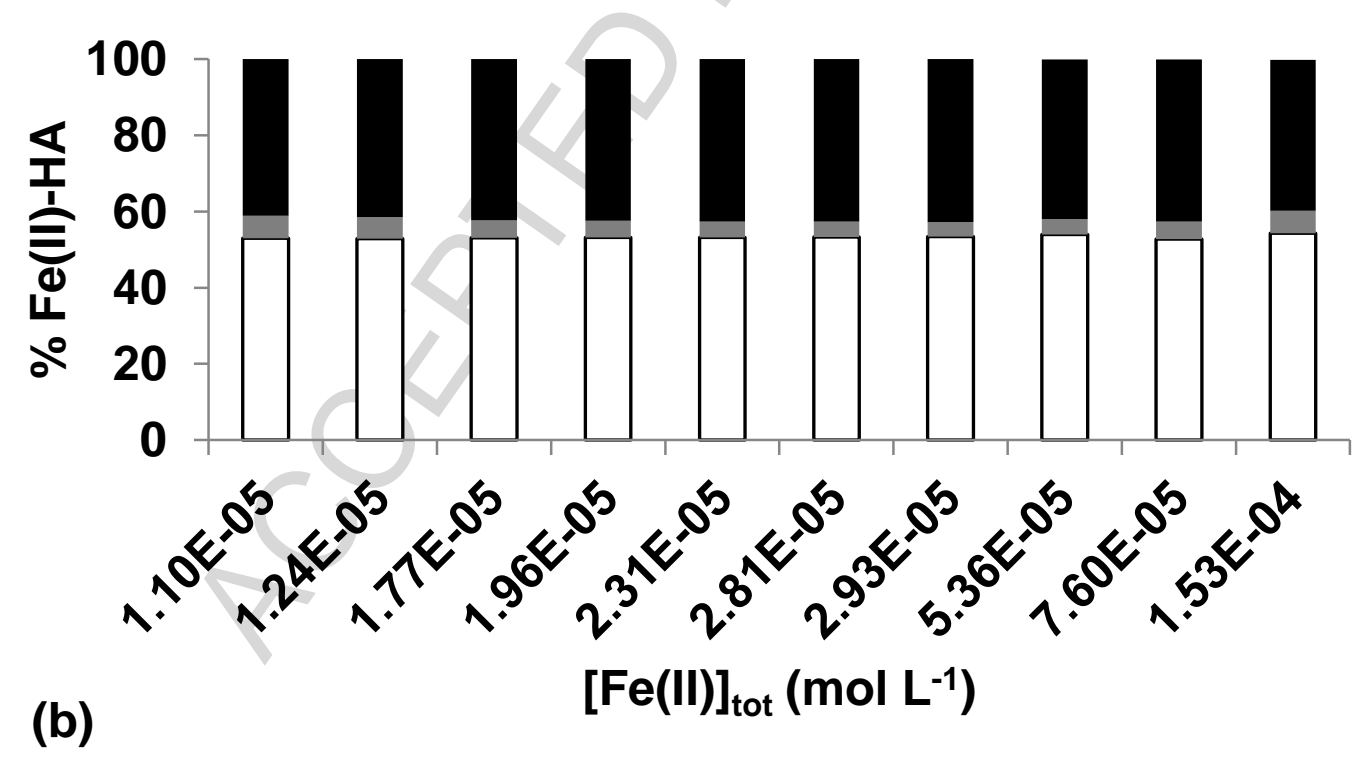

$\square$ Carboxylic sites $\square$ Phenolic sites $\square$ Carboxy-phenolic sites 


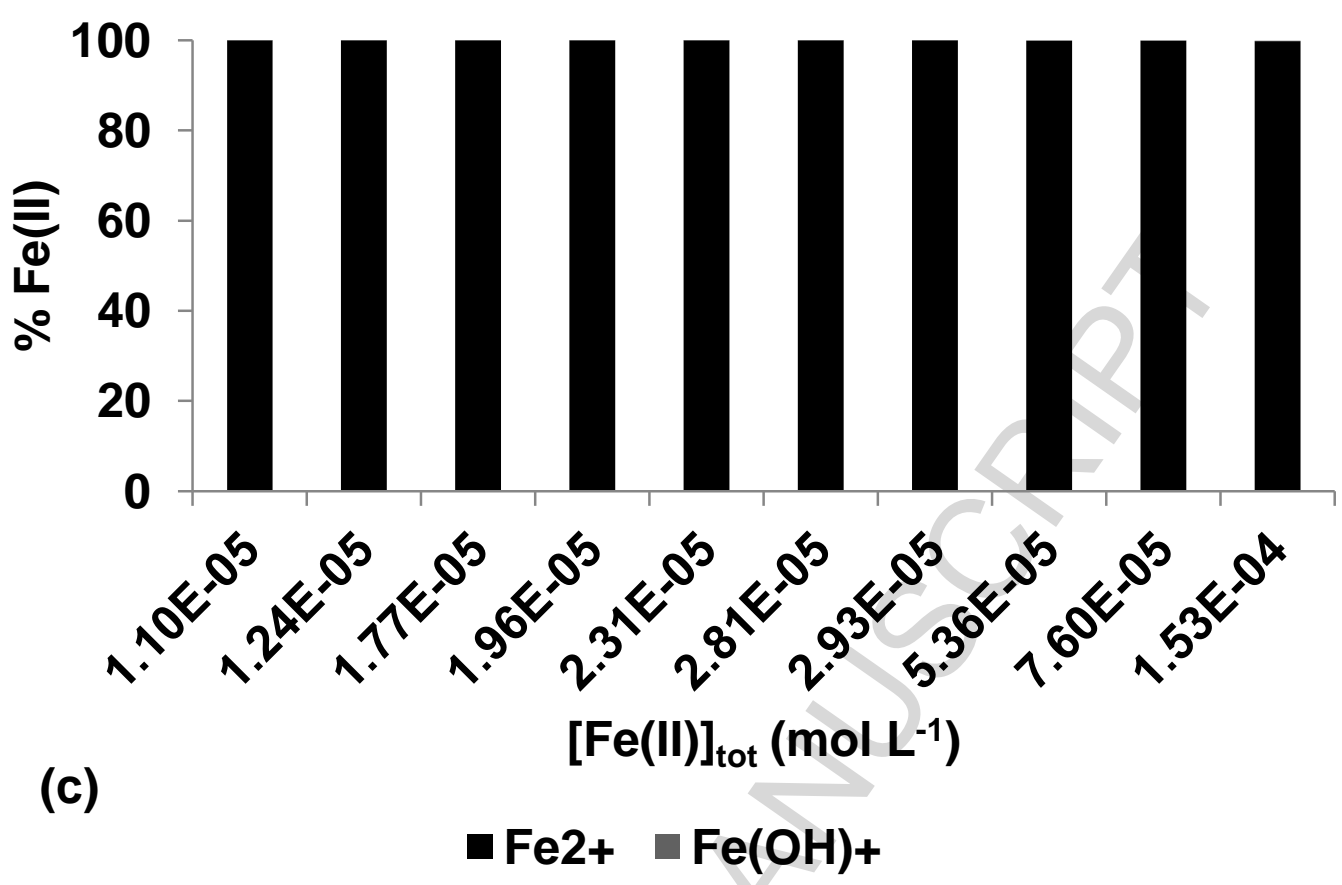

Fig. $2 \mathrm{Fe}$ (II) speciation onto the binding sites - adsorption isotherm (a) Denticity (b) Type of site (c) Form of adsorbed Fe(II). 


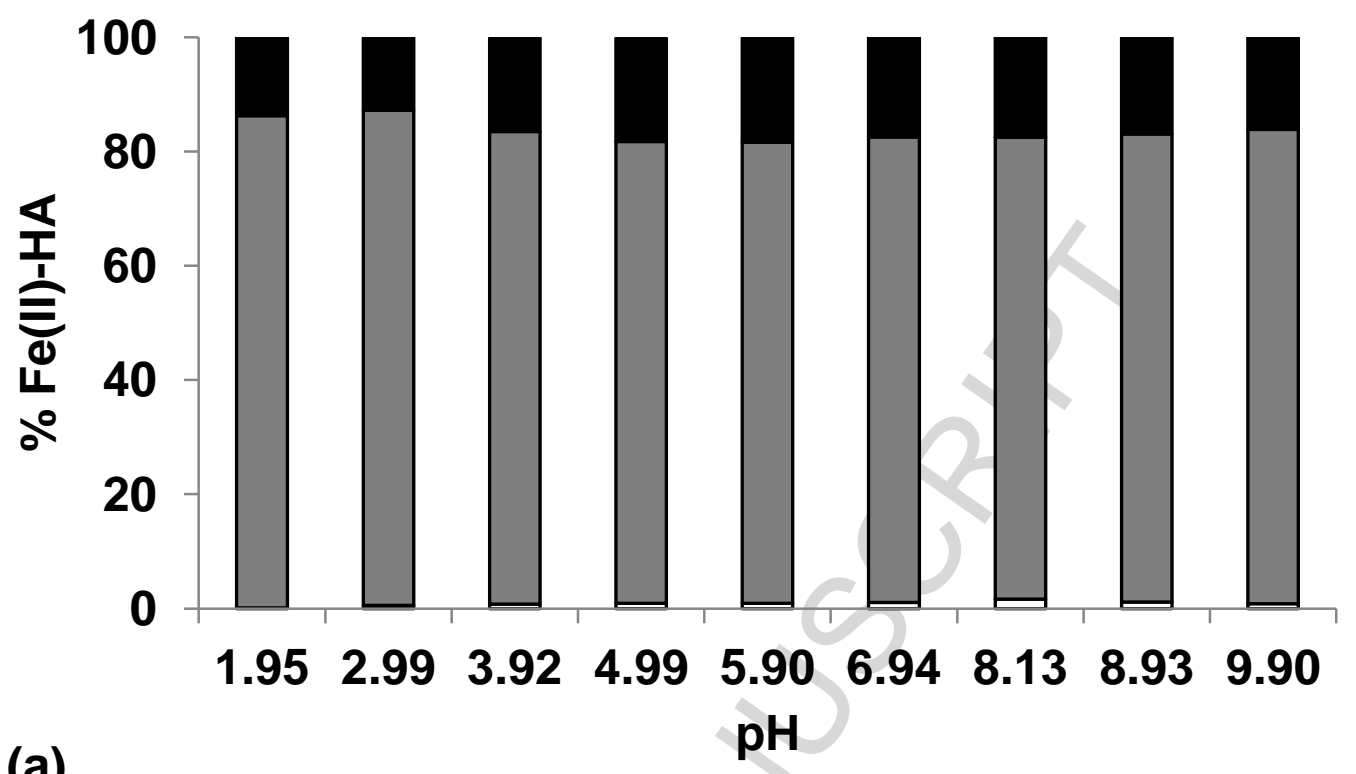

(a)

$\square$ Monodentates $\square$ Bidentates $\square$ Tridentates

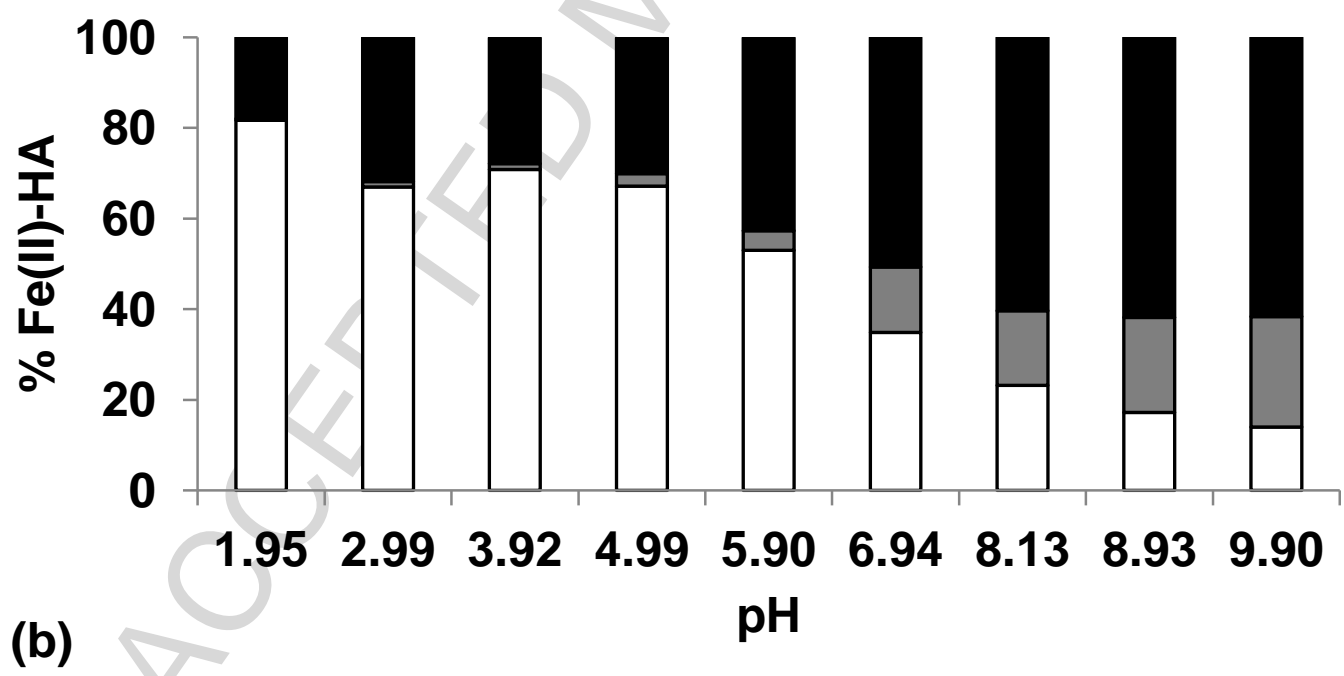

$\square$ Carboxylic sites $\square$ Phenolic sites $\square$ Carboxy-phenolic sites 


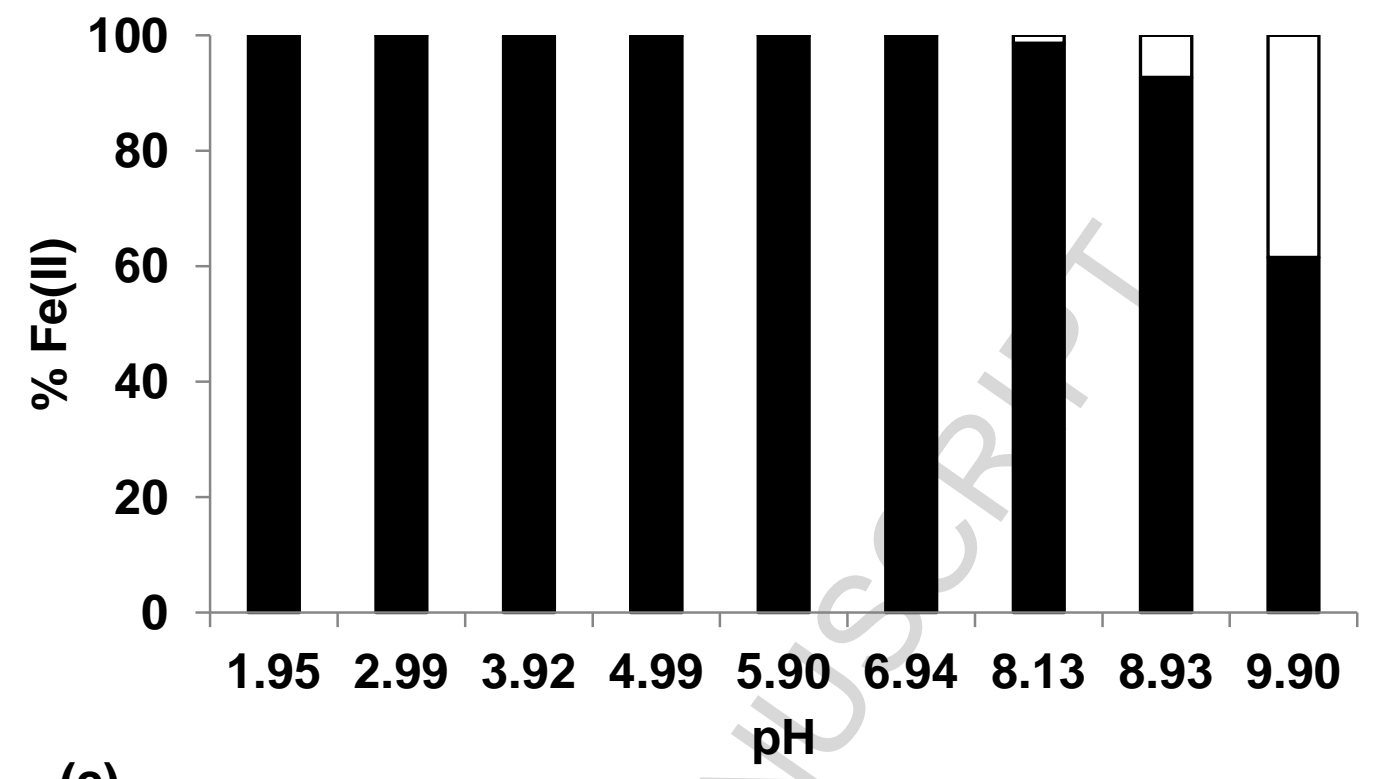

(c)

$\square \mathrm{Fe} 2+\square \mathrm{Fe}(\mathrm{OH})+$

Fig. $3 \mathrm{Fe}$ (II) speciation onto the binding sites - $\mathrm{pH}$ adsorption edge - DOC $=50 \mathrm{mg} \mathrm{L}^{-1}$ (a) Denticity, (b) Type of site, (c) Form of adsorbed Fe(II). 


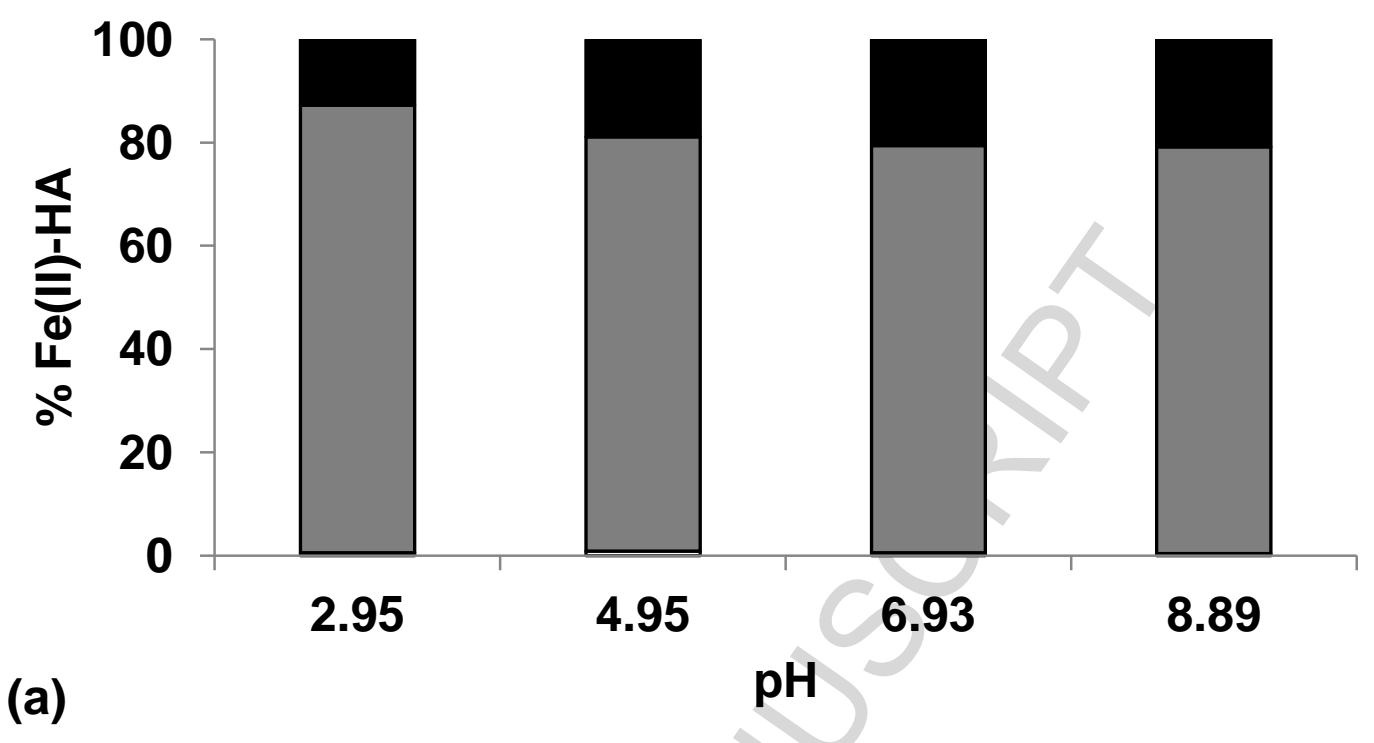

$\square$ Monodentates $\square$ Bidentates $\square$ Tridentates

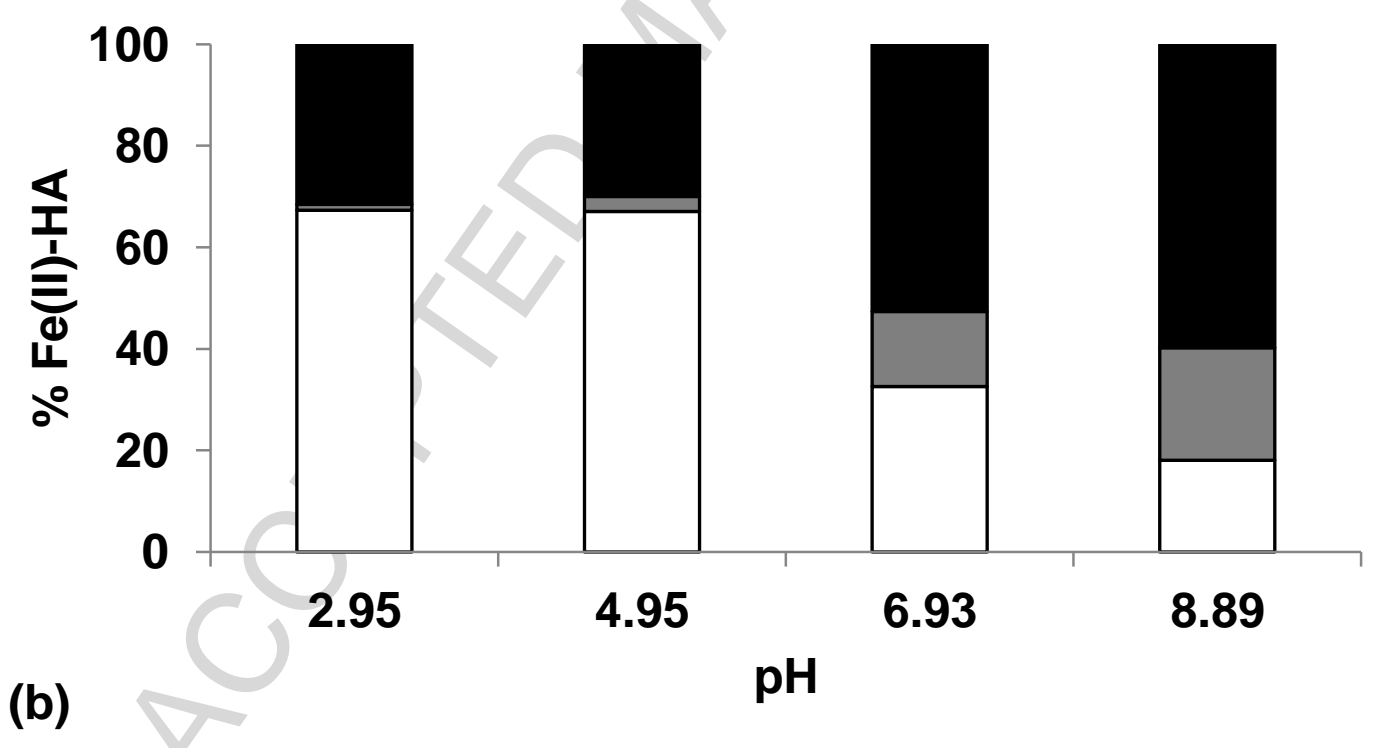

$\square$ Carboxylic sites $\square$ Phenolic sites $\square$ Carboxy-phenolic sites 


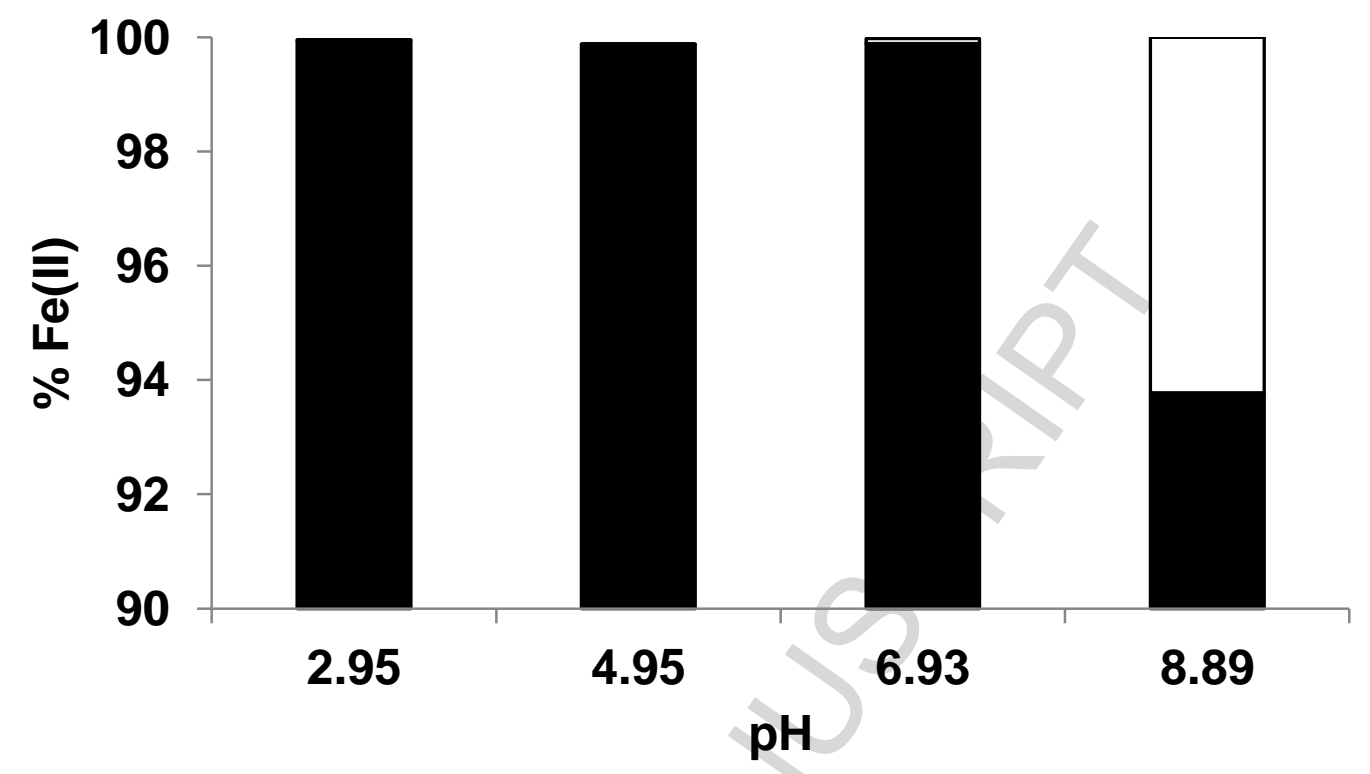

(c)

- $\mathrm{Fe} 2+\square \mathrm{Fe}(\mathrm{OH})+$

Fig. $4 \mathrm{Fe}$ (II) speciation onto the binding sites - $\mathrm{pH}$ adsorption edge - DOC $=76 \mathrm{mg} \mathrm{L}^{-1}$ (a) Denticity, (b) Type of site, (c) Form of adsorbed Fe(II). 


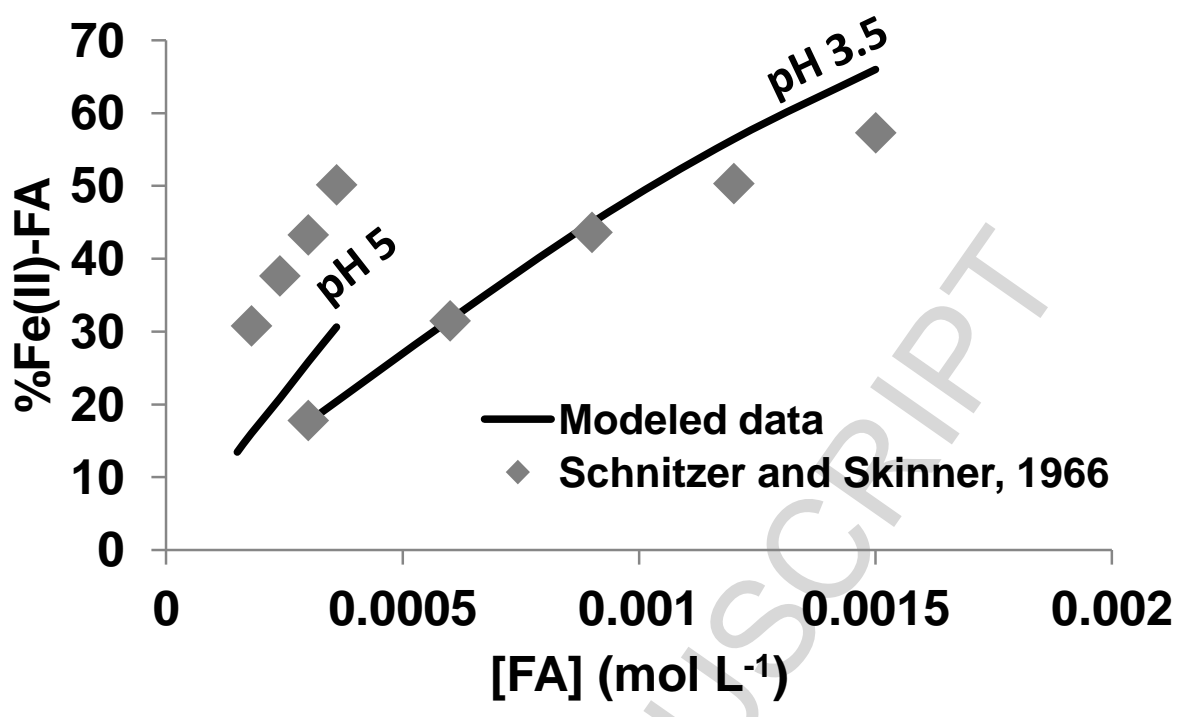

Fig. 5: Schnitzer and Skinner's dataset: experimental and modeled \% of Fe(II) adsorbed onto FA. 


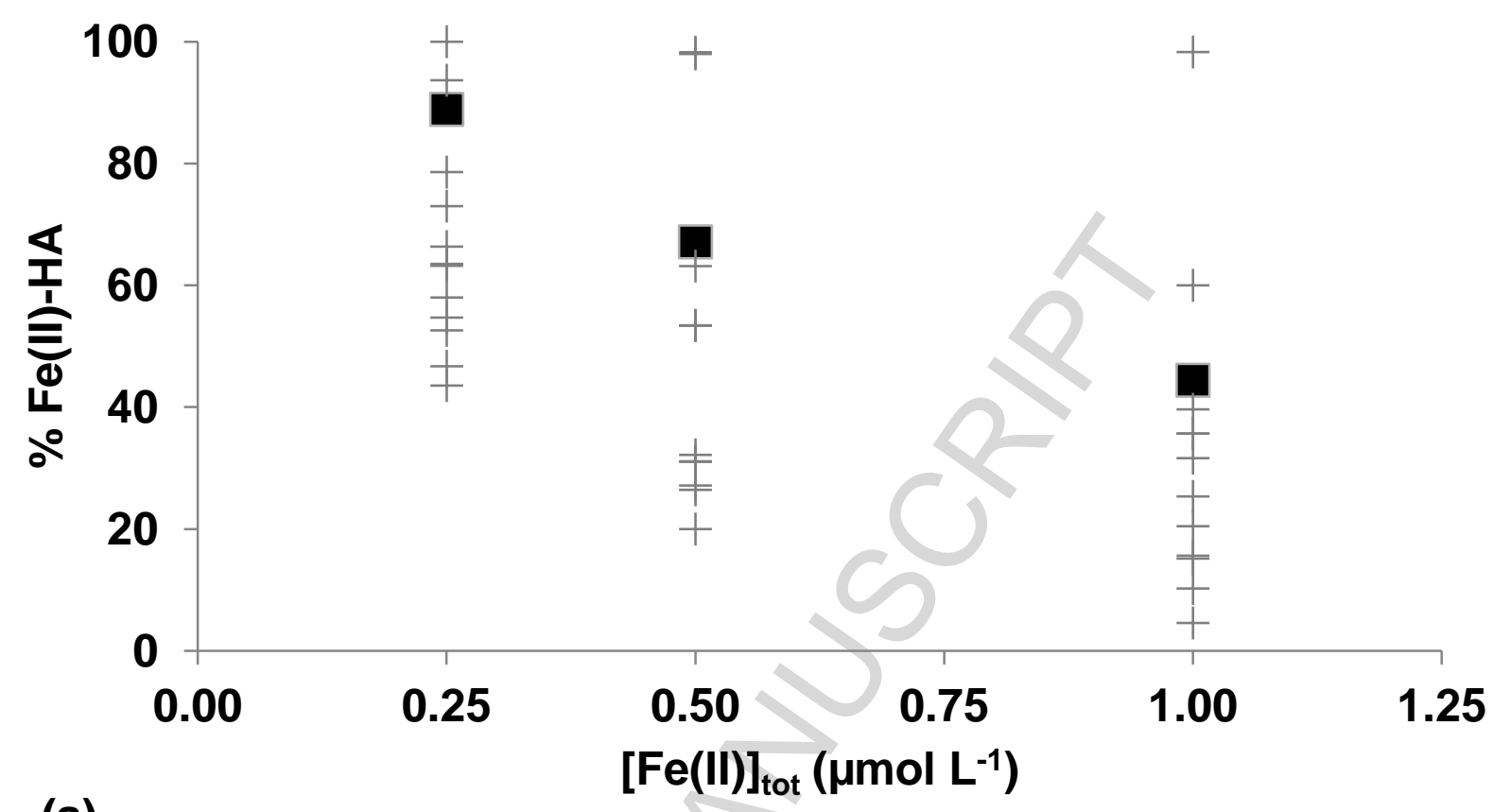

(a)

nodeled HA + Rose and Waite, 2003

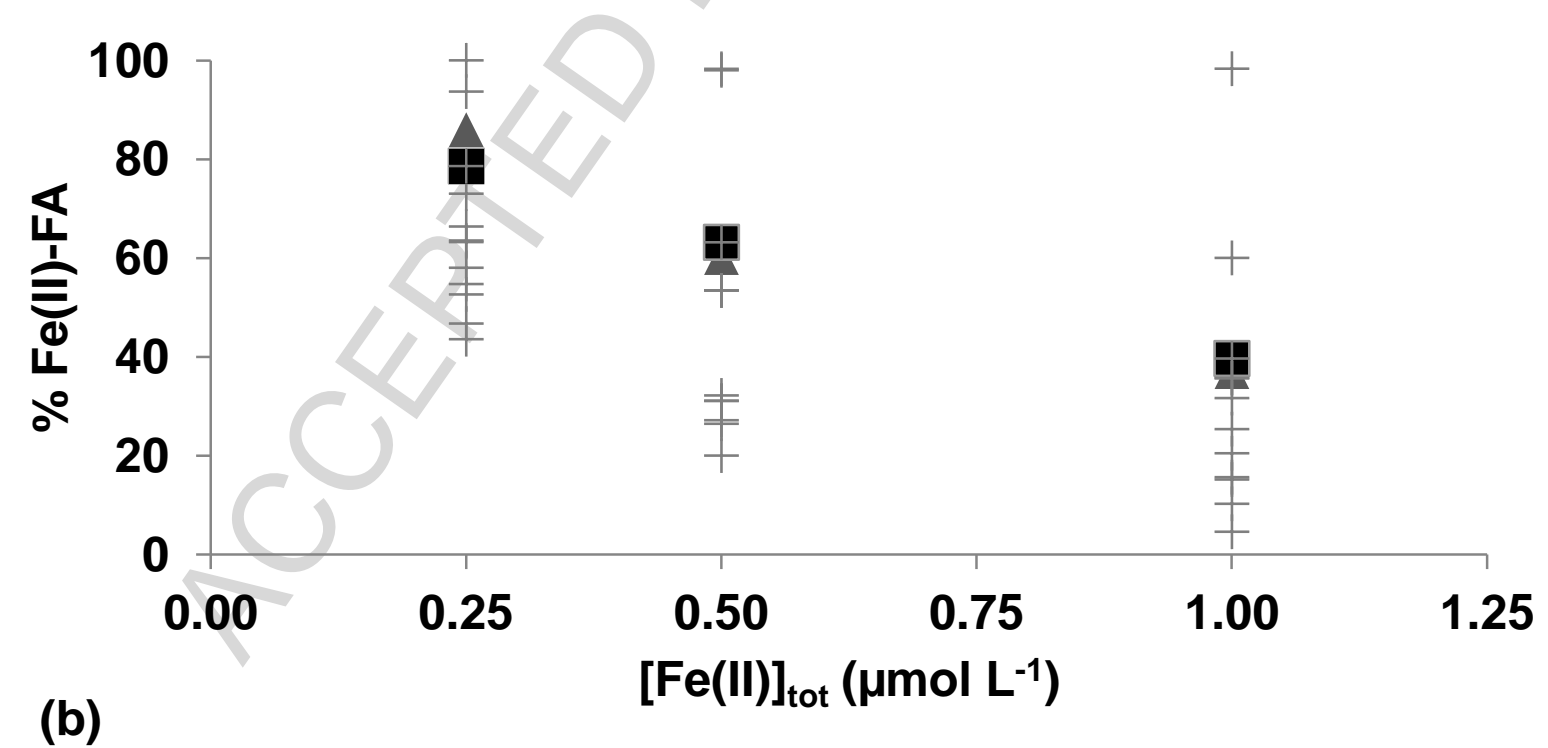

$\triangle$ Modeled FA $\square$ SRFA - Rose and Waite, 2003 + Rose and Waite, 2003

Fig. 6 Rose and Waite's dataset: (a) Comparison \% of Fe(II) adsorbed onto twelve different natural organic matters through an experimental approach and HA modeled data, (b) Experimental (SRFA)-mediated and modeled \% of $\mathrm{Fe}(\mathrm{II})$ adsorbed onto $\mathrm{FA}$. 


\section{Tables}

Table 1

PHREEQC-MOdel VI parameters for the humic and fulvic acids (Tipping, 2002)

\begin{tabular}{|c|c|c|c|}
\hline \multirow[t]{2}{*}{ Parameter } & \multirow[t]{2}{*}{ Description } & \multicolumn{2}{|l|}{ Values } \\
\hline & & $\mathrm{HA}$ & FA \\
\hline $\mathrm{n}_{\mathrm{A}}$ & Abundance of type $A$ sites $\left(\mathrm{mol} \mathrm{g}^{-1}\right)$ & 0.0033 & 0.0048 \\
\hline$n_{B}$ & Abundance of type B sites $\left(\mathrm{mol} \mathrm{g}^{-1}\right)$ & 0.001 & 0.0024 \\
\hline $\mathrm{pK}_{\mathrm{A}}$ & Intrinsic proton dissociation & 4.1 & 3.2 \\
\hline & constant for type A sites & & \\
\hline $\mathrm{pK}_{\mathrm{B}}$ & $\begin{array}{l}\text { Intrinsic proton dissociation } \\
\text { constant for type B sites }\end{array}$ & 8.8 & 9.4 \\
\hline$\Delta \mathrm{pK}_{\mathrm{A}}$ & Distribution term that modifies $\mathrm{pK}_{\mathrm{A}}$ & 2.1 & 3.3 \\
\hline$\Delta \mathrm{pK}_{\mathrm{B}}$ & Distribution term that modifies $\mathrm{pK}_{\mathrm{B}}$ & 3.6 & 4.9 \\
\hline$f_{B}$ & $\begin{array}{l}\text { Fraction of proton sites that can } \\
\text { make bidentate sites }\end{array}$ & 0.5 & 0.42 \\
\hline$f_{T}$ & $\begin{array}{l}\text { Fraction of proton sites that can } \\
\text { make tridentate sites }\end{array}$ & 0.065 & 0.03 \\
\hline $\log K_{M A}$ & $\begin{array}{l}\text { Intrinsic equilibrium constant for } \\
\text { metal binding at type A sites }\end{array}$ & Fitted $\mathrm{f}$ & al data \\
\hline $\log K_{M B}$ & $\begin{array}{l}\text { Intrinsic equilibrium constant for } \\
\text { metal binding at type B sites }\end{array}$ & Fitted $f$ & al data \\
\hline$\Delta \mathrm{LK}_{1 \mathrm{~A}}$ & $\begin{array}{l}\text { Distribution term that modifies log } \\
\mathrm{K}_{\mathrm{MA}}\end{array}$ & -0.7 & 0.5 \\
\hline$\Delta \mathrm{LK}_{1 \mathrm{~B}}$ & $\begin{array}{l}\text { Distribution term that modifies log } \\
\mathrm{K}_{\mathrm{MB}}\end{array}$ & 0.8 & 2.1 \\
\hline$\Delta \mathrm{LK}_{2}$ & $\begin{array}{l}\text { Distribution term that modifies the } \\
\text { strength of bidentate and tridentate } \\
\text { sites }\end{array}$ & Fitted $\mathrm{f}$ & al data \\
\hline
\end{tabular}

Table 2: $\log \mathrm{K}_{\mathrm{MA}}$, log $\mathrm{K}_{\mathrm{MB}}, \Delta \mathrm{LK}_{2 \mathrm{C}}$ and $\Delta \mathrm{LK}_{2 \mathrm{P}}$ values of the different species of Fe from Tipping (1998) (1) from this study (2), and from Marsac et al., 2013 (3).

\begin{tabular}{ccccc}
\hline Parameter & $\mathrm{Fe}^{2+} / \mathrm{FeOH}^{+(1)}$ & $\mathrm{Fe}^{2+} / \mathrm{Fe}(\mathrm{OH})^{+(2)}$ & $\mathrm{Fe}^{3+} / \mathrm{FeOH}^{2+(1)}$ & $\mathrm{Fe}^{3+} / \mathrm{FeOH}^{2+(3)}$ \\
\hline $\log \mathrm{K}_{\mathrm{MA}}$ & 1.3 & 2.19 & 2.5 & 3.5 \\
$\log \mathrm{K}_{\mathrm{MB}}$ & 3.257 & 4.46 & 7.325 & 6.9 \\
$\Delta \mathrm{LK}_{2 \mathrm{C}}$ & 0.81 & 3.9 & 2.2 & $4 / 0$ \\
$\Delta \mathrm{LK}_{2 \mathrm{P}}$ & 0.81 & 3.9 & 2.2 & $4 / 0$ \\
\hline
\end{tabular}




\section{Graphical Abstract:}

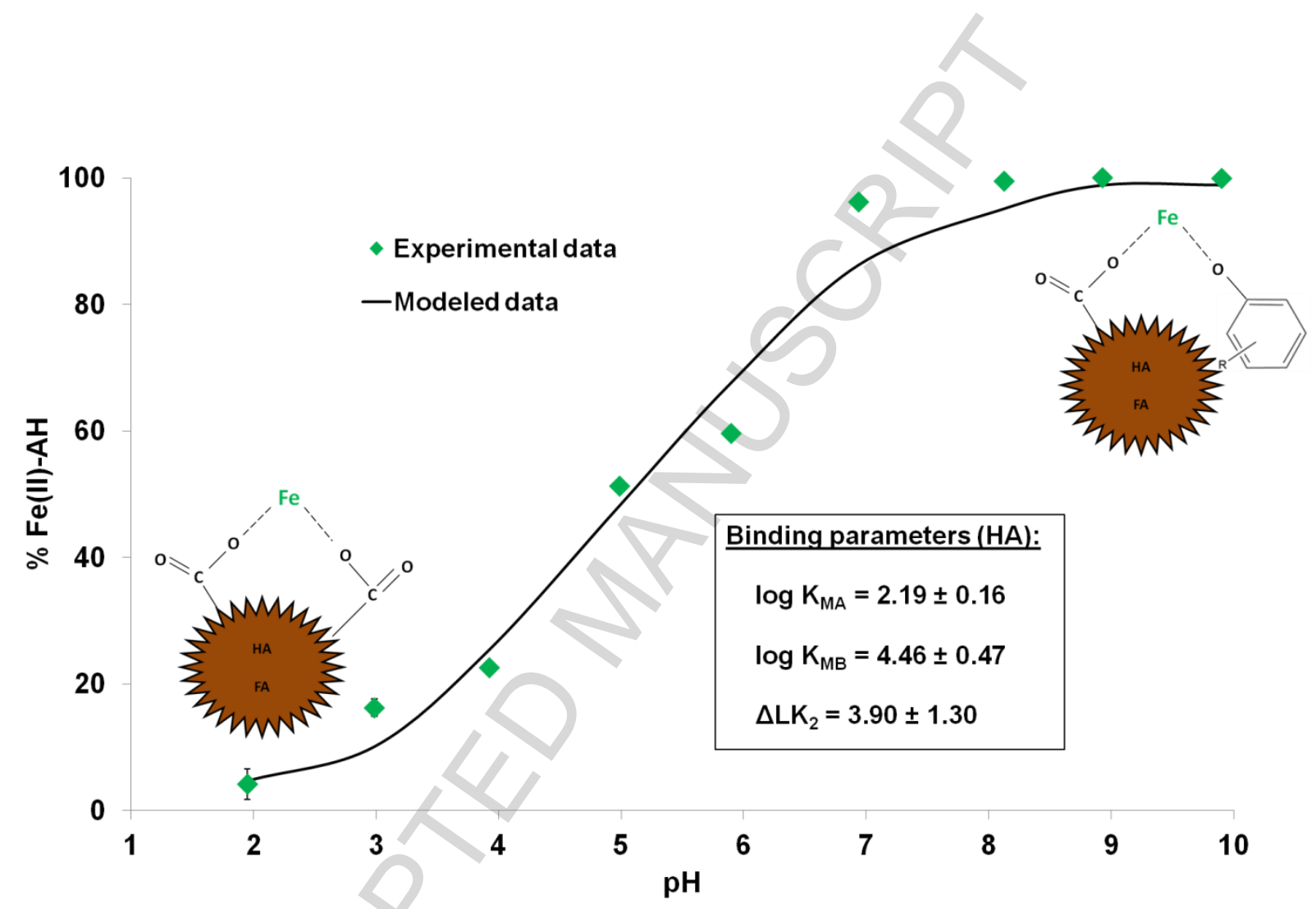




\section{Highlights:}

- We measured Fe(II)-Humic acid adsorption isotherm and $\mathrm{pH}$ sorption edge

- Results were modeled using a coupling of PHREEPLOT-PHREEQC-Model VI

- We determined the binding parameters for Fe(II)-humic acid complex

- We validated the binding parameters using LFERs and published datasets

- We determined the speciation of Fe(II)-humic acid complexes using PHREEQC-Model VI 